\title{
Use of Herbal Medicine by Pregnant Women: What Physicians Need to Know
}

\author{
Silvia M. Illamola ${ }^{1,2}$, Ogochukwu U. Amaeze ${ }^{3}$, Lubov V. Krepkova ${ }^{4}$, Angela K. Birnbaum ${ }^{2}$ \\ Ashwin Karanam ${ }^{2}$, Kathleen M. Job ${ }^{1}$, Valentina V. Bortnikova ${ }^{4}$, Catherine M.T. Sherwin ${ }^{1,5}$ \\ and Elena Y. Enioutina ${ }^{1,6,7 *}$

\begin{abstract}
${ }^{1}$ Division of Clinical Pharmacology, Department of Pediatrics, University of Utah School of Medicine, Salt Lake City, UT, United States, ${ }^{2}$ Department of Experimental and Clinical Pharmacology, College of Pharmacy, University of Minnesota, Minneapolis, MN, United States, ${ }^{3}$ Department of Clinical Pharmacy and Biopharmacy, Faculty of Pharmacy, University of Lagos, Lagos, Nigeria, ${ }^{4}$ Center of Medicine, All-Russian Research Institute of Medicinal and Aromatic Plants NILAR), Moscow, Russia, ${ }^{5}$ Department of Pharmacotherapy, College of Pharmacy, University of Utah, Salt Lake City, UT, United States, ${ }^{6}$ Department of Pathology, School of Medicine, University of Utah, Salt Lake City, UT, United States,

7 Pharmaceutics \& Pharmaceutical Chemistry, College of Pharmacy, University of Utah, Salt Lake City, UT, United States
\end{abstract}

\section{OPEN ACCESS}

Edited by:

Matitiahu Berkovitch,

Assaf Harofeh Medical Center, Israel

Reviewed by:

Shirley Seo,

United States Food and Drug

Administration, United States

Tony K. L. Kiang,

University of Alberta, Canada

${ }^{*}$ Correspondence:

Elena Y. Enioutina

elena.enioutina@hsc.utah.edu

Specialty section:

This article was submitted to Obstetric and Pediatric Pharmacology,

a section of the journal

Frontiers in Pharmacology

Received: 14 May 2019

Accepted: 15 November 2019

Published: 09 January 2020

Citation:

Illamola SM, Amaeze OU,

Krepkova LV, Birnbaum AK, Karanam A, Job KM, Bortnikova W, Sherwin CMT and Enioutina EY (2020)

Use of Herbal Medicine

by Pregnant Women:

What Physicians Need to Know.

Front. Pharmacol. 10:1483.

doi: 10.3389/fphar.2019.01483
About $80 \%$ of the consumers worldwide use herbal medicine (HMs) or other natural products. The percentage may vary significantly $(7 \%-55 \%)$ among pregnant women, depending upon social status, ethnicity, and cultural traditions. This manuscript discusses the most common HMs used by pregnant women, and the potential interactions of HMs with conventional drugs in some medical conditions that occur during pregnancy (e.g., hypertension, asthma, epilepsy). It also includes an examination of the characteristics of pregnant HM consumers, the primary conditions for which HMs are taken, and a discussion related to the potential toxicity of HMs taken during pregnancy. Many cultures have used HMs in pregnancy to improve wellbeing of the mother and/or baby, or to help decrease nausea and vomiting, treat infection, ease gastrointestinal problems, prepare for labor, induce labor, or ease labor pains. One of the reasons why pregnant women use HMs is an assumption that HMs are safer than conventional medicine. However, for pregnant women with pre-existing conditions like epilepsy and asthma, supplementation of conventional treatment with HMs may further complicate their care. The use of HMs is frequently not reported to healthcare professionals. Providers are often not questioning HM use, despite little being known about the HM safety and HM-drug interactions during pregnancy. This lack of knowledge on potential toxicity and the ability to interact with conventional treatments may impact both mother and fetus. There is a need for education of women and their healthcare professionals to move away from the idea of HMs not being harmful. Healthcare professionals need to question women on whether they use any HMs or natural products during pregnancy, especially when conventional treatment is less efficient and/or adverse events have occurred as herbaldrug interactions could be the reason for these observations. Additionally, more preclinical and clinical studies are needed to evaluate HM efficacy and toxicity.

Keywords: pregnancy, herbal medicine, herbal-drug interaction, efficacy, safety 


\section{INTRODUCTION}

The use of herbal medicines (HMs) (World Health Organization, Traditional, complementary and integrative medicine. Definitions, 2013), including medicinal herbs as botanical drugs, teas, dietary supplements (United States Congress), or indigenous formulation containing herbs, has increased significantly in the last two decades (Barnes, 2016; Sammons et al., 2016; Teng et al., 2016; Enioutina et al., 2017). Women are the primary consumers of HMs, and usually continue use during pregnancy (Dugoua, 2010). The prevalence of HM use during pregnancy ranges from $7 \%$ to $55 \%$ (Tiran, 2003), depending on consumers geographic location, ethnicity, cultural traditions, and social status (Dugoua, 2010). For example, 34\% of Australian (Frawley et al., 2013), 50\% of European Union (Lapi et al., 2010; Holst et al., 2011), and 6\%-9\% of the USA and Canadian (Moussally et al., 2009; Louik et al., 2010) pregnant women are using HMs. Pregnant women usually perceive herbal products as a safe, natural alternative to conventional drugs (Frawley et al., 2015) and often use them to improve their wellbeing or for the treatment of non-life threating conditions (e.g., nausea, constipation).

A number of HMs or dietary supplements, such as uterine stimulants and labor inducers \{e.g., Black cohosh (Actaea racemosa L.), and Blue cohosh [Caulophyllum thalictroides (L.) Michx.]\} (Dugoua et al., 2006; Dugoua et al., 2008; Frawley et al., 2015), have a long, documented history of use. However, while the adverse effects of these herbal treatments are documented (Smeriglio et al., 2014), data on their safety during pregnancy is generally insufficient. In most countries, HMs are available over the counter, making them very accessible. HMs can represent a problem when self-prescribed by pregnant women along clinician-prescribed conventional drugs (Low Dog, 2009). As patients do not recognize them as potentially harmful compounds, HM use is not always reported to healthcare professionals (Adams, 2011).

The main purpose of this scoping review is to inform healthcare professionals regarding HMs commonly used by pregnant women and potential interactions of these HMs with conventional drugs used for the treatment of some preexisting medical conditions or those that occur during pregnancy (e.g., hypertension, asthma, epilepsy). Hypertensive disorders during pregnancy, including chronic hypertension, gestational hypertension, preeclampsia, and chronic hypertension with superimposed preeclampsia, represent about $10 \%$ of pregnancy complications in the USA (Lai et al., 2017). Asthma is a common preexisting condition affecting about $9 \%$ of pregnant women (Kwon et al., 2006). Epilepsy is another common preexisting disease in pregnant women. It has been reported that use of antiepileptic drugs (AEDs) by pregnant women may be associated with an increase in adverse outcomes such as miscarriage, antepartum, and post-partum hemorrhages (Viale et al., 2015). This manuscript also includes an examination of the characteristics of pregnant $\mathrm{HM}$ consumers, the primary conditions for which HMs are taken, and a discussion related to the potential toxicity of HMs taken during pregnancy.

\section{METHODS}

The study undertaken by our group was a scoping review of the literature aimed at identifying literature describing 1) medicinal herb and traditional medicine use by women during pregnancy and 2) gaps in the pre-clinical and clinical research associated with the use of medicinal herbs and traditional remedies by pregnant women. A comprehensive search was conducted by six reviewers in two electronic databases (PubMed and Embase) and relevant medicinal herbs websites for articles published between January 1983 and December 2018. Searches were conducted using a base of keywords: medicinal herbs, phytomedicine, traditional medicine, conventional drugs, herb-drug interaction, adverse drug (herb) reactions, hypertension treatment, asthma treatment, epilepsy treatment, pregnancy, and pregnant women. Combinations and variations of keywords were also used. Bibliographies of all relevant eligible articles were reviewed for further potential references. Pre-clinical animal, in vitro study, and clinical trial data reported in the selected articles were categorized into thematic groups related to the study objectives.

\section{CONSUMPTION OF HMS BY PREGNANT WOMEN}

Multiple studies over the last decade reveal that pregnant women may take a variety of HMs as crude herbal preparations, herbal extracts, finished and labeled medicinal products of herbal origin as well as dietary supplements consisting of proprietary blends of HMs, vitamins, and minerals. The most commonly used HMs were ginger (Zingiber officinale Roscoe), chamomile (Matricaria chamomilla L.), peppermint (Mentha piperita L.), Echinacea [Echinacea purpurea (L.) Moench], cranberry (Vaccinium oxycoccus L. and Vaccinium macrocarpum L.), garlic (Allium sativum L.), raspberry (Rubus idaeus L.), valerian (Valeriana officinalis L.), fenugreek (Trigonella foenum-graecum L.), fennel (Foeniculum vulgare Mill.), herbal blends, and teas including green and black teas [Camellia sinensis (L.) Kuntze] (Adams et al., 2009; Hall et al., 2011; Kennedy et al., 2013; John and Shantakumari, 2015; Teni et al., 2017). Herbal products (e.g., ginger, garlic, and various herbal teas) were frequently used by pregnant women worldwide, while others were region-specific. For example, motherwort (Leonurus cardiaca L.), centaury (Centaurium erythraea Rafn.), and lovage (Levisticum officinale W.D.J.Koch) were mostly used by women from Eastern European countries while Uva ursi [Arctostaphylos uva-ursi (L.) Spreng.] was used by women living in Western and Eastern European countries (Kennedy et al., 2013). Floradix ${ }^{\circledR}$ IRON + HERBS, ginseng, and valerian were often used by Swedish women during pregnancy (Holst et al., 2008).

The indications for the use of HMs during pregnancy may vary and can be either mother- or child-related. HMs may be used sometimes as a part of maternal care to treat pregnancy-related problems, and often to improve the well-being of the mother or unborn child. The most commonly reported indications were nausea and vomiting, urinary tract infections (UTIs), preparation for and/or facilitation of labor, cold or flu, gastrointestinal issues, 
pain conditions, improvement of fetal outcomes, prevention of miscarriage, anxiety, health maintenance, and edema (Hall et al., 2011; Kennedy et al., 2013; John and Shantakumari, 2015; Teni et al., 2017). The most common herbal products consumed during pregnancy and their indications are described in Table $\mathbf{1 .}$

While the use of HMs for the above described indications is not country specific, some indications for HM use were more prominent within particular regions. For example, pregnant women in India and Ghana were more likely to use HMs to prevent miscarriage and improve the health status of the unborn baby than their counterparts in the developed nations (Adusi-Poku et al., 2015; Bhatt, 2016). Common fetal-related indications were an improvement of fetal physical and mental growth (Rahman et al., 2008; Adusi-Poku et al., 2015; Mugomeri et al., 2015; Bhatt et al., 2016; Dika et al., 2017), prevention of neonatal hyperbilirubinemia (Tabatabaee, 2011), or even protecting the unborn baby from evil (Maputle et al., 2015). Remarkably, some indications were firmly ingrained in the cultural beliefs of women. For instance, most women in Lesotho used HMs during pregnancy simply because it was a tradition (Mugomeri et al., 2015). Similarly, in Zimbabwe, the use of antenatal HMs was carried over from previous generations. Pregnant women were culturally obliged to use traditional treatments, sometimes against their personal preference (Panganai and Shumba, 2016).

The use of indigenous medicinal plants as a part of antenatal care was common in developing nations, such as in Africa and Asia (Mureyi et al., 2012; Al-Ramahi et al., 2013; Elkhoudri et al., 2016; Maputle et al., 2015; Tang et al., 2016; Onyiapat et al., 2017). Such medicinal plants were typically consumed in a crude form, or as infusions, decoctions, and tinctures. The "Isihlambezo" decoction for instance, was used as a tonic by pregnant Zulu women in South Africa during the last trimester of pregnancy (Varga and Veale, 1997; Brookes, 2018). "Isihlambezo," comprised of several medicinal plants, was strongly believed to "promote a favorable course of pregnancy and facilitate quick and uncomplicated labor" (Veale et al., 1992; Varga and Veale, 1997; Naidu, 2014; Brookes, 2018). The four most frequently cited components of this decoction are Clivia miniata (Lindl.) Verschaff., Agapanthus africanus (L.) Hoffmanns, Pentanisia prunelloides (Klotzsch ex Eckl. \& Zeyh.) Walp., and Gunnera perpensa L. (Brookes, 2018). The recipes depend on a number of factors including the traditional healer preferences, the woman's health status, and many other factors (Veale et al., 1992). This decoction possesses direct uterotonic activity. When used at a high dose, it may cause excessive uterine stimulation leading to

TABLE 1 | Commonly used herbal medicines (HMs) by pregnant women worldwide.

Indications

Morning

sickness,

nausea, vomiting

Cold and flu

Pain (gastralgia

and other types

of pain)

Anxiety, stress

Gastrointestinal

disorders,

constipation,

flatulence

Edema

Urinary tract

infection

Labor

preparation,

facilitation and

induction

Milk production

and secretion

Fetal health

promotion
Medicinal herbs

Ginger (Zingiber officinale Roscoe), Peppermint (Mentha piperita L.), Herbal teas, Raspberry (Rubus idaeus L.), Bishop's weed (Aegopodium podagraria L.), Garlic (Allium sativum L.), Anise (Pimpinella anisum L.)

Madder (Rubia tinctorum L.), Anise (Pimpinella anisum L.), Golden buttons (Matricaria aurea (Loefl.) Sch. Bip.), Wild thyme (Origanum syriacum L.), Liquorice (Glycyrrhiza glabra L.), Borage (Borago officinalis L.), Chamomille (Matricaria chamomilla L.), Ginger (Zingiber officinale Roscoe), Echinacea (Echinacea purpurea L.), Eucalyptus (Eucalyptus spp.), Rosehip (Rosa spp.)

Verbena triphylla (Aloysia citriodora Palau), Anise (Pimpinella anisum L.), Cumin (Cuminum cyminum L.), Fennel (Foeniculum vulgare Mill.), Golden buttons [Matricaria aurea (Loefl.) Sch. Bip.], Peppermint (Mentha piperita L.), Wild thyme (Origanum syriacum L.), Sage (Salvia officinalis L.), Cinnamon (Cinnamomum verum J. Presl), Black cumin (Nigella ciliaris DC.), Chamomille (Matricaria chamomilla L.)

Anise (Pimpinella anisum L.), Peppermint (Mentha piperita L.), Chamomille (Matricaria chamomilla L.), Thyme (Thymus vulgaris L.), Rosemary (Rosmarinus officinalis L.), Valerian (Valeriana officinalis L.)

Fennel (Foeniculum vulgare Mill.), Anise (Pimpinella anisum L.), Borage (Borago officinalis L.), Chamomille (Matricaria chamomilla L.), Ginger (Zingiber officinale Roscoe), Peppermint (Mentha piperita L.), Senna (Cassia senna), Green tea (Camellia sinensis), Cinnamon (Cinnamomum verum J. Presl)

\author{
Turmeric (Curcuma longa L.), Fennel (Foeniculum vulgare Mill.)
}

Cranberry (Vaccinium macrocarpon L.), Bearberry [Arctostaphylos uva-ursi) (L.) Spreng.], Parsley [Petroselinum crispum (Mill.) Fuss], Fenugreek (Trigonella foenum-graecum L.), Rosemary (Rosmarinus officinalis L.), Peppermint (Mentha piperita L.), Sage (Salvia officinalis L.)

Rooibos [Aspalathus linearis (Burm.f.) R. Dahlgren] tea, coconut (Coco nucifera L.) oil, Date palm (Phoenix dactylifera L.), Golden buttons [Matricaria aurea (Loefl.) Sch. Bip.], Watercress (Nasturtium officinale W.T. Aiton), Cinnamon (Cinnamomum verum J. Pres), Fenugreek (Trigonella foenumgraecum), Rosemary (Rosmarinus officinalis L.), Raspberry (Rubus idaeus L.), Cannabis sativa L., Evening primrose (Oenothera biennis L.)

Madder (Rubia tinctorum L.), Caraway (Carum carvi L.), Fenugreek (Trigonella foenum-graecum L.), Cinnamon (Cinnamomum verum J. PresI), Cumin (Cuminum cyminum L.), Fennel (Foeniculum vulgare Mill.)

Gingko (Gingko biloba), Ganoderma (Ganoderma lucidum), Sage (Salvia fruticosa), Olibanum (Boswellia serrata Triana \& Planch.)

Anemia

Spinach (Spinacia oleracea L.), Fenugreek (Foeniculum vulgare Mill.), Cinnamon (Cinnamomum verum J. Presl), Rosehip (Rosa spp.) 
adverse reactions. The adverse effects linked to "Isihlambezo" formulation include low neonatal birth-weights, fetal meconium staining, which was a sign of possible fetal distress and hypoxia, and fatal uterine rupture (Veale et al., 1998). The "Mwanamphepo" preparation, which contains several plants [e.g., Ampelocissus obtusata (Welw. ex Baker) Planch., Cyphostemma hildebrandtii (Gilg) Desc. ex Wild \& R.B.Drumm, and Cissus verticillata (L.) Nicolson \& C.E.Jarvis], was commonly used in Malawi to induce labor (Maliwichi-Nyirenda and Maliwichi, 2010). It was allegedly mixed with porridge and consumed by pregnant women beforelabor (Maliwichi-Nyirenda and Maliwichi, 2010). The self-reported use of 'Mwanamphepo" preparation during pregnancy in rural Malawi was associated with increased morbidity of mothers and increased mortality and morbidity of neonates (Zamawe et al., 2018). In Korea, the herbal formulation "Anjeonicheon-tang" containing Atractylodes macrocephala Koidzumi white rhizoma, Glycyrrhiza glabra L. rhizoma, Panax ginseng C.A.Mey. rhizoma, and other medicinal plants was frequently used during pregnancy for pregnancy-related symptoms, especially hyperemesis gravidarum (Jo et al., 2016). “An-Tai-Yin” containing numerous medicinal herbs in formulation is consumed by pregnant women in Taiwan (Chuang et al., 2009). An-Tai-Yin use was associated with an increased risk of congenital malformations of the fetal eye, musculoskeletal, and connective tissues (Chuang et al., 2006).

It appears that HM use was prevalent in the first and third trimesters of pregnancy (John and Shantakumari, 2015; Pallivalapila et al., 2015). HM was usually used in the first trimester for prevention and/or treatment of early pregnancyrelated issues such as nausea, vomiting, and gastrointestinal disorders. During the third trimester, they were commonly used to prepare the uterus for labor and ease child delivery (Mureyi et al., 2012; Nyeko et al., 2016; Onyiapat et al., 2017). Nonetheless, it was not uncommon for women to use HMs throughout all trimesters of pregnancy, usually with the intent to improve the well-being of the mother and unborn child. No particular trends have been revealed by researchers (Nordeng and Havnen, 2004; Rahman et al., 2008; Tabatabaee, 2011; Tang et al., 2016). In some cases, the women simply continued using the herbal products until they "felt better" (Nergard et al., 2015).

The majority of pregnant women preferring complementary or alternative medicine containing HMs were married women with secondary schooling or university degrees (Zaffani et al., 2006; Adams et al., 2009; Kennedy et al., 2013; Kennedy et al., 2016). These HMs users were nonsmokers over 30 years old with higher incomes and a prior history of the HM use (Forster et al., 2006; Adams et al., 2009; Kennedy et al., 2013; Kennedy et al., 2016). In Eastern European countries, HM use was more prevalent among younger pregnant women (less than 20 years) (Kennedy et al., 2013). In African and Asian regions, women who use HMs during pregnancy were less than 30 years old, with little or no formal education, of low socioeconomic status, and living in rural areas far from public health facilities (John and Shantakumari, 2015; Teni et al., 2017).

The majority of pregnant women relied extensively on family members, relatives, and friends in their decisions to use HMs during pregnancy (Kennedy et al., 2013; John and Shantakumari,
2015). Other essential referral sources, particularly in Africa, were traditional birth attendants, local herb sellers, and herbalists (Teni et al., 2017). In developed nations, the media was one of the supporting sources in the decision regarding HM use during pregnancy (Hall et al., 2011). Pregnant women from the Eastern European countries frequently made their decisions based on advice of a treating physician (Kennedy et al., 2013). Concomitant consumption of HMs and conventional drugs by pregnant women is quite common worldwide (Holst et al., 2008; Tamuno et al., 2010; Holst et al., 2011; Tabatabaee, 2011; Nyeko et al., 2016). The simultaneous use of HMs and conventional drugs may result in a decrease of drug efficacy or toxicity resulting from herb-drug interactions. However, women often withhold this information on HM use from their healthcare professional because the use of $\mathrm{HMs}$ is not part of conventional treatment.

Our review of the literature has shown that while use of HMs by pregnant women may vary depending on region, cultural traditions, age, and education, the majority of pregnant women actively use various HMs and traditional remedies to prevent or treat conditions associated with pregnancy, to ease labor, and also to improve baby development after labor. This urgently necessitates the exploration of HMs and traditional herbal formulations for their safety and efficacy in pregnant animals or potentially women taking this HMs.

\section{EFFICACY AND SAFETY OF HMS USED BY PREGNANT WOMEN}

The information on safety and efficacy of medicinal herbs generally comes from the experience of past generations. Preclinical and clinical studies completed in the last two to three decades have provided scientific evidence of the efficacy and safety of some medicinal herbs and herbal formulations.

Pre-clinical in vivo and in vitro studies describing potential embryotoxicity have been conducted for certain HMs. An extensive search conducted by Jurgens in 2003 revealed a few studies that scientifically evaluated safety of HMs, including blue cohosh [C. thalictroides (L.) Michx.], ginger (Z. officinale Roscoe), ginkgo (Ginkgo biloba L.), Siberian ginseng [Eleutherococcus senticosus (Rupr. \& Maxim.) Maxim.], phytoestrogens, pyrrolizidine alkaloids, scullcap (Scutellaria lateriflora L.), St. John's Wort (Hypericum perforatum L.), and valerian (V. officinalis L.) (Jurgens, 2003). Ginkgo was the only HM with no teratogenic or embryotoxic effects reported. The use of the other HMs was associated with embryotoxicity.

An in vitro study of the effects of ginsenosides, the bioactive component of ginseng, on the developing embryo during the critical period of organogenesis demonstrated that they exert direct teratogenic effects on rat embryos (Chan et al., 2003). Veale et al. (1998) studied the effects of several plant extracts commonly used as ethnic herbal oxytocics: C. miniata (Lindl.) Verschaff. (umayimi), A. africanus (L.) Hoffmanns (ubani), $P$. prunelloides (Klotzsch ex Eckl. \& Zeyh) Walp (icishamlilo), G. perpensa L. (ugobo), Rhoicissus tridentata (L.f.) Wild \& 
R.B.Drumm. (isinwazi), and Combretum erythrophyllum (Burch.) Sond. and Combretum kraussii Hochst. (umdubu) for their embryotoxicity. Based on results from an isolated rat uterus model, the authors concluded that the oxytocic activity of these plants can lead to fetal hypoxia and premature delivery as a result of uterine hyperstimulation. Mahmoudian et al. (Mahmoudian et al., 2012) investigated the effects of valerian (V. officinalis L.) extract on brain development and function in the brain tissues of murine fetuses. They found that the use of valerian during midgestation caused a significant decrease in zinc level in the fetal brain, an essential element affecting brain development. In our opinion, the use of valerian preparations should be limited during pregnancy. The treatment of pregnant rats with of thermopsis (Thermopsis lanceolata R.Br.), an HM with expectorant properties, resulted in a decrease of the body weight and craniocaudal measurements of 20-day old fetuses (Krepkova et al., 2016). Thermopsis did not affect the survival rate of pups in the postpartum period, but altered vestibular functions, motor coordination, and emotional-motor behaviors of pups born from mothers exposed to HM. Therefore, thermopsis and preparations containing thermopsis should not be recommend for the use during pregnancy.

The above reviewed studies have shown that HMs may possess embryotoxic, teratogenic effects, or may stimulate premature labor in preclinical studies. It is not known if these effects are also extant in humans. This explains why there are very few studies investigating efficacy and safety of HMs in pregnant women. Knowing that pre-clinical studies of HMs demonstrate embryotoxic effects and/or defects in offspring development, in our opinion, it would be unethical to do prospective studies; however, review of retrospective clinical studies would be helpful to identify clinically relevant herbrelated birth defects.

Leung and colleagues performed a retrospective study comparing the differences in the neonatal development of babies born from pregnant women who took either HMs or pharmaceutical products for the treatment of flu and some chronic medical problems, as well as for weight reduction, menstrual problems, and infections (Leung et al., 2002). The prevalence of congenital fetal abnormalities in the group of women who took HMs was higher, but not statistically significant, than that in the group of women who took pharmaceutical products. There were neither differences in the proportion of silent miscarriages nor in the presence of abnormal karyotypes between the two groups. Although the authors did not find differences in the teratogenicity associated with HMs and PPs. However, several limitations of the study suggest that more research is needed to draw more certain conclusions. Other studies concluded that the use of HMs during pregnancy may be associated with congenital malformations or even with fetal distress (Mabina et al., 1997). Takei et al. reported a case of occipital meningoencephalocele and cerebellar agenesis in a neonate born at 38 weeks of gestation that was associated with the use of Tripterygium wilfordii Hook.f. for the treatment of rheumatoid arthritis early in pregnancy (Takei et al., 1997).
There are several clinical trials conducted to determine the clinical effects of HMs in pregnant women, but only a few of them can be classified as high-quality, randomized controlled trials (RCTs). Table 2 summarizes the main characteristics of some of the clinical trials investigating the clinical effects of HMs in pregnant women (Dante et al., 2013). Of the 17 clinical trials described here, only 8 studied the efficacy of HMs in pregnant women. Eleven clinical trials explored the effects of ginger $(Z$. officinale Roscoe) (Fischer-Rasmussen et al., 1991; Vutyavanich et al., 2001; Keating and Chez, 2002; Willetts et al., 2003; Sripramote and Lekhyananda, 2003; Smith et al., 2004; Chittumma et al., 2007; Pongrojpaw et al., 2007; Ensiyeh and Sakineh, 2009; Ozgoli et al., 2009; Sharifzadeh et al., 2018), one studied cranberry (Vaccinium macrocarpon L.) (Wing et al., 2008), one investigated raspberry leaf in tablets ( $R$. idaeus L.) (Simpson et al., 2001), one reviewed garlic (A. sativum L.) (Ziaei et al., 2001), one evaluated the use of St. John's Wort $(H$. perforatum L.) (Samadi et al., 2010), one clinical trial explored the effects of chamomile (M. chamomilla L.) (Zafar et al., 2016), and another clinical trial investigated peppermint aromatherapy (M. piperita L.) (Joulaeerad et al., 2018).

The most studied HM was ginger. From the 11 RCTs described, 6 investigated ginger compared to placebo (FischerRasmussen et al., 1991; Vutyavanich et al., 2001; Keating and Chez, 2002; Willetts et al., 2003; Ozgoli et al., 2009; Sharifzadeh et al., 2018), 4 to pyridoxine (vitamin $\mathrm{B}_{6}$ ) (Sripramote and Lekhyananda, 2003; Smith et al., 2004; Chittumma et al., 2007; Ensiyeh and Sakineh, 2009), and 1 to dimenhydrinate (Pongrojpaw et al., 2007). When compared to placebo, all trials showed superiority of ginger in the management of nausea and vomiting except one (Willetts et al., 2003). When compared to vitamin $\mathrm{B}_{6}$, results were not homogeneous. No differences were found between ginger and dimenhydrinate groups in controlling either nausea or vomiting.

Few RCTs were conducted to study other HM efficacy and safety in pregnant women. Only one RCT was identified exploring the effects of cranberry compared with placebo in the prevention of UTIs among pregnant women (Wing et al., 2008). The incidence of UTIs or neonatal outcomes were not different between groups; however, this study did not have enough power to detect such a difference. The Cochrane Collaboration reviewed the use of cranberry for the prevention and treatment of UTIs in women in 2008 (Jepson and Craig, 2008). The review concluded that cranberry use significantly reduced the incidence of symptomatic UTIs, but pregnant women were not included in these studies. Another RCT investigated the use of raspberry leaf during pregnancy (Simpson et al., 2001). Consumption of raspberry leaf tablets from 32 weeks of pregnancy until labor resulted in a shorter second stage of labor and in a decrease of the rate forceps delivery when compared to the control group. Consumption of raspberry leaf tablets had no adverse effects on mothers and newborns. A randomized, single-blind, placebo clinical trials investigated the effects of garlic tablets ( $800 \mathrm{mg} /$ day) taken by pregnant women during the third trimester of pregnancy on plasma lipids, platelet aggregation, and the ability to prevent preeclampsia (Ziaei et al., 
TABLE 2 | Clinical trials on safety and/or efficacy of herbal products in pregnancy.

\begin{tabular}{|c|c|c|c|c|}
\hline $\begin{array}{l}\text { Herbal } \\
\text { medicine }\end{array}$ & $\begin{array}{l}\text { Study } \\
\text { design }\end{array}$ & $\begin{array}{l}\text { Number of } \\
\text { subjects }\end{array}$ & Dose/duration & Main findings \\
\hline \multirow[t]{11}{*}{ Ginger } & $\begin{array}{l}\text { Double-blind } \\
\text { randomized } \\
\text { cross-over }\end{array}$ & $\begin{array}{l}\mathrm{N}=15 \text { treatment } \\
\mathrm{N}=15 \text { lactose }\end{array}$ & $1 \mathrm{~g} /$ day 4 days & $\begin{array}{l}\text { Better than placebo on nausea and vomiting. } \\
\text { All infants were without deformities and discharges in good conditions (Fischer- } \\
\text { Rasmussen et al., 1991). }\end{array}$ \\
\hline & $\begin{array}{l}\text { Double-blind } \\
\text { randomized } \\
\text { controlled }\end{array}$ & $\begin{array}{l}\mathrm{N}=35 \text { treatment } \\
\mathrm{N}=32 \text { placebo }\end{array}$ & $1 \mathrm{~g} /$ day 4 days & $\begin{array}{l}\text { Better than placebo on nausea and vomiting. } \\
\text { No increase of number of spontaneous abortions, term deliveries, and number } \\
\text { of cesareans. No recognized congenital anomalies (Vutyavanich et al., 2001). }\end{array}$ \\
\hline & $\begin{array}{l}\text { Double-blind } \\
\text { randomized } \\
\text { controlled }\end{array}$ & $\begin{array}{l}\mathrm{N}=14 \text { treatment } \\
\mathrm{N}=11 \text { placebo }\end{array}$ & $1 \mathrm{~g} /$ day 2 weeks & $\begin{array}{l}\text { Better than placebo on nausea and vomiting. } \\
\text { Viable infants at term without major complications (Willetts et al., 2003). }\end{array}$ \\
\hline & $\begin{array}{l}\text { Double-blind } \\
\text { randomized } \\
\text { controlled }\end{array}$ & $\begin{array}{l}\mathrm{N}=48 \text { treatment } \\
\mathrm{N}=51 \text { placebo }\end{array}$ & 6 g/day 4 days & $\begin{array}{l}\text { Better than placebo on nausea and retching. } \\
\text { Equal to placebo on vomiting. No increased risk of fetal abnormalities, low } \\
\text { birthweight and Apgar scores compared with general population of infants born } \\
\text { at the same hospital and year (Willetts et al., 2003). }\end{array}$ \\
\hline & $\begin{array}{l}\text { Single-blind } \\
\text { randomized } \\
\text { controlled }\end{array}$ & $\begin{array}{l}\mathrm{n}=32 \text { treatment } \\
\mathrm{n}=35 \text { placebo }\end{array}$ & $1 \mathrm{~g} /$ day 4 days & Better than placebo on nausea and vomiting (Ozgoli et al., 2009). \\
\hline & $\begin{array}{l}\text { Double-blind } \\
\text { randomized } \\
\text { controlled }\end{array}$ & $\begin{array}{l}\mathrm{N}=64 \text { treatment } \\
\mathrm{N}=64 \\
\text { vitamin } \mathrm{B}_{6}\end{array}$ & $\begin{array}{l}1.5 \mathrm{~g} / \text { day Vitamin } \mathrm{B}_{6}: 30 \mathrm{mg} / \text { day } \\
\qquad 3 \text { days }\end{array}$ & $\begin{array}{l}\text { Equal to vitamin } B_{6} \text { on nausea and vomiting. (Sripramote and Lekhyananda, } \\
\text { 2003) }\end{array}$ \\
\hline & $\begin{array}{l}\text { Double-blind } \\
\text { randomized } \\
\text { controlled }\end{array}$ & $\begin{array}{l}\mathrm{N}=146 \\
\text { treatment } \\
\mathrm{N}=145 \\
\text { vitamin } \mathrm{B}_{6}\end{array}$ & $\begin{array}{l}1.05 \mathrm{~g} / \text { day Vit } \mathrm{B}_{6}: 75 \mathrm{mg} / \text { day } \\
\text { 3 weeks }\end{array}$ & $\begin{array}{l}\text { Equal to vitamin } B_{6} \text { on nausea, retching, and vomiting. } \\
\text { No differences in number of congenital abnormalities or other birth outcomes } \\
\text { (gestational age, live births, abortions, stillbirths, birth weight) between groups } \\
\text { (Smith et al., 2004). }\end{array}$ \\
\hline & $\begin{array}{l}\text { Double-blind } \\
\text { randomized } \\
\text { controlled }\end{array}$ & $\begin{array}{l}\mathrm{N}=61 \\
\text { treatment } \\
\mathrm{N}=62 \\
\text { vitamin } \mathrm{B}_{6}\end{array}$ & $\begin{array}{l}1.95 \mathrm{~g} / \text { day Vitamin } \mathrm{B}_{6}: 25 \mathrm{mg} / \text { day } \\
\qquad 4 \text { days }\end{array}$ & Better than vitamin $B_{6}$ on nausea and vomiting (Chittumma et al., 2007). \\
\hline & $\begin{array}{l}\text { Triple-blind } \\
\text { randomized } \\
\text { controlled }\end{array}$ & $\begin{array}{l}\mathrm{N}=28 \text { treatment } \\
\mathrm{N}=26 \text { vitamin } \\
\mathrm{B}_{6} \\
\mathrm{~N}=23 \text { placebo }\end{array}$ & $\begin{array}{l}500 \mathrm{mg} \text { BID } 4 \text { days } 40 \mathrm{mg} \\
\text { BID } 4 \text { days } 4 \text { days }\end{array}$ & $\begin{array}{l}\text { Ginger is more effective than placebo at reducing nausea and vomiting; } \\
\text { however, vitamin } B_{6} \text { was also effective compared to placebo. (Chittumma et al., } \\
\text { 2007; Sharifzadeh et al., 2018) }\end{array}$ \\
\hline & $\begin{array}{l}\text { Double-blind } \\
\text { randomized } \\
\text { controlled }\end{array}$ & $\begin{array}{l}\mathrm{N}=35 \text { treatment } \\
\mathrm{N}=34 \\
\text { vitamin } \mathrm{B}_{6}\end{array}$ & $\begin{array}{l}1 \mathrm{~g} / \text { day Vitamin } \mathrm{B}_{6} \text { : } \\
40 \mathrm{mg} / \text { day } 4 \text { days }\end{array}$ & $\begin{array}{l}\text { Better than vitamin } B_{6} \text { on nausea. Equal to vitamin } B_{6} \text { on vomiting. } \\
\text { No increase of number of spontaneous abortions, term deliveries, and number } \\
\text { of cesareans. No recognized congenital anomalies (Ensiyeh and Sakineh, 2009). }\end{array}$ \\
\hline & $\begin{array}{l}\text { Double-blind } \\
\text { randomized } \\
\text { controlled }\end{array}$ & $\begin{array}{l}\mathrm{N}=77 \\
\text { treatment } \\
\mathrm{N}=74 \\
\text { dimenhydrimate }\end{array}$ & $\begin{array}{l}1 \mathrm{~g} / \text { day dimenhydrimate: } \\
100 \mathrm{mg} 1 \text { week }\end{array}$ & Equal to dimenhydrimate on nausea and vomiting (Pongrojpaw et al., 2007). \\
\hline Cranberry & $\begin{array}{l}\text { Randomized, } \\
\text { controlled }\end{array}$ & $\begin{array}{l}\mathrm{N}=58 \\
\text { treatment } \mathrm{A} \\
\mathrm{N}=67 \\
\text { treatment } \mathrm{B} \\
\mathrm{N}=63 \text { placebo }\end{array}$ & $\begin{array}{l}\text { A: } 240 \mathrm{mg} / \text { day } \\
\text { B: } 80 \mathrm{mg} / \text { day Until delivery }\end{array}$ & $\begin{array}{l}\text { No statistically significant difference between the treatments. } \\
\text { No differences on neonatal outcomes between the groups (Wing et al., 2008). }\end{array}$ \\
\hline $\begin{array}{l}\text { Raspberry } \\
\text { leaf }\end{array}$ & $\begin{array}{l}\text { Double-blind } \\
\text { randomized } \\
\text { controlled }\end{array}$ & $\begin{array}{l}\mathrm{N}=96 \text { treatment } \\
\mathrm{N}=96 \text { placebo }\end{array}$ & $\begin{array}{l}2.4 \mathrm{~g} / \text { day } \\
\text { From } 32 \text { weeks to labor }\end{array}$ & $\begin{array}{l}\text { No statistically significant difference in duration of labor, length of gestation } \\
\text { period, medical augmentation of labor, need for epidural block, or cesarean } \\
\text { section rate (Simpson et al., 2001). }\end{array}$ \\
\hline Garlic & $\begin{array}{l}\text { Single-blind } \\
\text { randomized } \\
\text { controlled }\end{array}$ & $\begin{array}{l}\mathrm{N}=50 \text { treatment } \\
\mathrm{N}=50 \text { placebo }\end{array}$ & 800 mg/day 8 weeks & $\begin{array}{l}\text { No statistically significant difference in the means of HDL, LDL, triglyceride, } \\
\text { inhibition of platelet aggregation, means of systolic and diastolic blood pressure. } \\
\text { Statistically significant difference in the means of total cholesterol and } \\
\text { hypertension alone. (Ziaei et al., 2001) }\end{array}$ \\
\hline Chamomile & $\begin{array}{l}\text { Double-blind } \\
\text { randomized } \\
\text { controlled }\end{array}$ & $\begin{array}{l}\mathrm{N}=42 \text { treatment } \\
\mathrm{N}=47 \\
\text { Pentazocine } \\
\mathrm{N}=42 \text { placebo }\end{array}$ & $\begin{array}{l}1 \mathrm{ml} \text { of saline }+3 \text { drops of } 1 \mathrm{M} \\
\text { solution of chamomile } 1 \mathrm{ml} \text { of } \\
\text { Pentazocine }(30 \mathrm{mg})+\text { oral placebo } \\
1 \mathrm{ml} \text { of saline }+ \text { oral placebo }\end{array}$ & $\begin{array}{l}\text { No adverse events were noted. } \\
\text { Chamomile and Pentazocine did not significantly differ from placebo (Zafar et al., } \\
\text { 2016). }\end{array}$ \\
\hline Peppermint & & $\begin{array}{l}\mathrm{N}=28 \text { treatment } \\
\mathrm{N}=28 \text { placebo }\end{array}$ & $10 \%$ & $\begin{array}{l}\text { There were no statistical significant difference in nausea symptoms between } \\
\text { groups; however, improvement in symptoms were observed in both treatment } \\
\text { and placebo arms (Joulaeerad et al., 2018). }\end{array}$ \\
\hline $\begin{array}{l}\text { St John's } \\
\text { Wort }\end{array}$ & $\begin{array}{l}\text { Double-blind } \\
\text { randomized } \\
\text { controlled }\end{array}$ & $\begin{array}{l}\mathrm{N}=47 \text { treatment } \\
\mathrm{N}=44 \text { placebo } \\
\mathrm{N}=34 \text { control }\end{array}$ & Oily extract 16 days & $\begin{array}{l}\text { Statistically significant difference in wound healing and scar formation between } \\
\text { the three groups (Samadi et al., 2010). }\end{array}$ \\
\hline
\end{tabular}

$H D L$, high-density lipoporotein; LDL, low-density lipoporotein. 
2001). The authors did not find significant differences in plasma high-density lipoprotein, low-density lipoprotein, and triglyceride levels or inhibition of platelet aggregation between case and control groups. Garlic treatment did not prevent preeclampsia, but did reduce total cholesterol levels and incidence of hypertension in pregnant women (Ziaei et al., 2001). It has been suggested that high cholesterol levels as well as gestational or chronic hypertension are associated with negative effects on mother and fetus health (Bartels and O'Donoghue, 2011; Mustafa et al., 2012). Therefore, reduction of cholesterol and blood pressure levels may lead to the reduction of unfavorable pregnancy outcomes. Samadi et al. investigate the effects of St. John's Wort ointment on cesarean wound healing and on the formation of hypertrophic scars in Iranian women giving birth by cesarean section (Samadi et al., 2010). It was concluded that St. John's Wort ointment application enhanced wound healing and reduced hypertrophic scar formation. Zafar et al. investigated the efficacy of chamomile as a labor analgesic in a randomized, placebo controlled, double-blind RCT (Zafar et al., 2016). No significant analgesic or adverse effects were observed between group using chamomile and control group. Similarly, Joulaeerad et al. studied the effectiveness of peppermint aromatherapy on pregnancyrelated nausea and vomiting in a single-blind RCT (Joulaeerad et al., 2018). Investigators did not observe significant reduction in nausea and vomiting in women receiving peppermint aromatherapy compared with the placebo group.

Overall, data regarding the safety and efficacy of many HMs commonly used during pregnancy are limited. HMs used in clinical trials were not always standardized to bioactive constituents and often have limited quality control. This lack of standardization makes conclusions sometimes controversial, with no specific recommendations about herbal use by pregnant women. The duration of the treatment is usually very short, and most of them are small in scale, often $10-15$ women. It is difficult to estimate a specific number of individuals needed to be recruited, as significance depends on some other factors. We believe that further studies should be performed with larger samples sizes ( $\mathrm{n}=30-50$ per groups) and studies should include all trimesters to make these determinations. However, these clinical trials should take in consideration data received in preclinical in vivo or in vitro studies of HMs. In our opinion, it will be unethical to conduct clinical trials of HMs with potential embryotoxicity in pregnant women. Additionally, treating physicians need to be aware of potential embryotoxicity of certain HMs and advise against use of these HMs by pregnant women.

\section{HERBAL-DRUG INTERACTIONS}

\section{Epilepsy in Pregnancy and HM Use}

It is not uncommon for women with epilepsy to be of a childbearing age. There is little evidence substantiating the use of herbals for the treatment of seizures. In fact, the use of certain HM may increase the frequency of seizures, cause side effects or interact with conventional AEDs. One herbal product (extracts of the Cannabis sativa L. plant) has been approved by the Food and Drug Administration for treating certain seizure types (HIGHLIGHTS OF PRESCRIBING INFORMATION).

Cannabidiol extracted from $C$. sativa has been approved for use in certain types of seizure disorders. Although extracts of the cannabis plant have been readily available in some countries, they have not been accessible for patients in the United States until recently. There is a broad spectrum of products with some including other cannabinoids such as tetrahydrocannabiol. Use of cannabis during pregnancy has been shown to be associated with adverse outcomes for both infant and mother (Gunn et al., 2016). In vitro studies indicate that cannabidiol inhibits several cytochrome enzymes including CYP3A4, CYP3A5, and CYP2D6 (Yamaori et al., 2011a; Yamaori et al., 2011b), but induces CYP1A1 (Yamaori et al., 2015). Additionally, in an in vitro study, cannabidiol has been shown to induce UDP-glucuronosyltransferases UGT1A9 and UGT2B7 (Al Saabi et al., 2013). This could lead to complex interactions with AEDs metabolized by these pathways, increasing or decreasing their plasma levels increasing the risk of therapeutic failure or adverse effects. Cannabidiol has been reported to have interactions with several AEDs including clobazam, rufinamide, topiramate, zonisamide, and eslicarbazepine (Gaston et al., 2017).

As there is little evidence available for the use of other HMs in epilepsy patients, there is even less accessible to support use in pregnancy. Some AEDs exhibit complicated pharmacokinetics, and additional medications or HMs have the potential to interact leading to the potential to effect therapy. Some commonly used HMs by patients with epilepsy are St. John's Wort ( $H$. perforatum L.), Gingko (Gingko biloba L.), Borgae (Borago officinalis L.), Valerian (V. officinalis L.), and Cannabis ( $C$. sativa L.) (Spinella, 2001; Liu et al., 2017).

St. John's Wort (H. perforatum L.) is used as a complementary medicine for mild depression (Linde et al., 1996; Kim et al., 1999; Linde and Mulrow, 2000) and some psychiatric indications (Martinez et al., 1994; Kasper, 1997; Taylor and Kobak, 2000). There is some evidence for minimal risk of St. John Wort's use in pregnancy (Grush et al., 1998). Preclinical studies in animals demonstrated that exposure to this HM during pregnancy does not impair cognitive function or have any long-term adverse effects on fetus (Rayburn et al., 2000; Rayburn et al., 2001). However, there are several interactions of St. John's Wort with AEDs (Wang et al., 2001; Schulz, 2001; Henderson et al., 2002; Markowitz et al., 2003; Durr et al., 2000). These interactions involve induction/inhibition of cytochrome P450 enzyme systems that metabolize AEDs, leading to toxicity from overexposure or reduced efficacy from sub-therapeutic levels. Based on an in vitro data it is predicted that St John's Wort reduces concentrations of CYP3A4 substrates (Komoroski et al., 2004). However, it does not seem to further induce carbamazepine clearance after 14 days of treatment in healthy volunteers (Burstein et al., 2000).

Gingko, an extract from the leaves and seeds of the plant G. biloba L. has been used in the treatment of Alzheimer's (Kanowski et al., 1996; Oken et al., 1998) and premenstrual syndrome (Tamborini and Taurelle, 1993). It is reported to be pro-convulsive in animal models (Pilija et al., 2004) and initiates seizures in children (Fessenden et al., 2001). Gingko has been considered relatively safe (Hashiguchi et al., 
2015), however caution should be used during lactation, as it partitions into breast-milk (Romaszko et al., 2014).

Flowers of $B$. officinalis L. containing alkaloids, especially pyrrolizidine, are consumed as an herbal tea. The AED, phenobarbital causes structural changes in pyrolizidine chemistry, rendering it carcinogenic and teratogenic (Kast, 2001; Roeder et al., 2015). Pyrrolizidine has also been implicated in inducing premature labor by behaving as a prostaglandin E agonist (Kast, 2001).

Root extracts prepared from $V$. officinalis L. are used for the treatment of insomnia (Ziegler et al., 2002) and anxiety (Kohnen and Oswald, 1988). Although valerian has been implicated in the inhibition of CYP3A4 and P-glycoprotein (Hellum and Nilsen, 2008), no clinically relevant interactions with medications metabolized by these enzymes have been observed (Donovan et al., 2004).

In summary, management of epilepsy in pregnancy can be complicated and challenging due to changing physiology and pharmacokinetics. HMs have the potential to interact with the AED therapy leading to reduced efficacy and increased complications during pregnancy increases the risk to both mother and fetus. Healthcare providers should counsel women with epilepsy about the risks of concurrent use, especially during pregnancy.

\section{Hypertension in Pregnancy and HM Use}

Hypertensive disorders of pregnancy include chronic hypertension, gestational hypertension, preeclampsia, and chronic hypertension with superimposed preeclampsia (Lai et al., 2017). Hypertension can be one serious complication of pregnancy leading to potential mortality and morbidity of the mother and fetus (Mustafa et al., 2012). Nowadays, the frequency of preeclampsia defined as a new onset of hypertension accompanied by the proteinuria occurring after 20 weeks of gestation (Mustafa et al., 2012; Townsend et al., 2016 ) is on the rise due to the increasing number of older women or women with comorbidities becoming pregnant (Townsend et al., 2016). Preeclampsia can significantly contribute to premature labor and maternal mortality (Townsend et al., 2016). Additionally, preeclampsia may affect multiple organs and systems resulting in impairment of the cardiovascular (e.g., acute respiratory distress syndrome, cardiomyopathy), neurons (e.g., eclampsia, cerebral thrombosis, and hemorrhage), renal and hepatic systems (acute kidney injury, glomerular endotheliosis, hepatic periportal inflammation, acute fatty liver of pregnancy).

Antihypertensive therapy during pregnancy is aimed to reduce the risk of severe hypertension and subsequent morbidities (e.g., renal injury). Labetalol is a first-line antihypertensive therapy recommended for the treatment of the moderate hypertension (Committee on Obstetric P, 2017). Methyldopa and nifedipine can be used as alternative drugs, while the use of angiotensinconverting enzyme drugs is not recommended in pregnancy (Committee on Obstetric P, 2017). Recent evidence-based recommendations on the treatment of acute onset of severe hypertension in pregnancy were released by the American College of Obstetricians and Gynecologists in 2017 (Committee on Obstetric P, 2017). Immediate release oral nifedipine was recommended as first-line therapy for pregnant women with acute onset of hypertension. Intravenous administrations of labetalol or hydralazine were also suggested (Committee on Obstetric P, 2017).

Labetalol and nifedipine are the two most commonly used drugs during pregnancy. Nifedipine is metabolized by the CYP3A4 enzyme and eliminates from the human body as pyridine and carboxylic acid of nifedipine (Zisaki et al., 2015). In the human body, labetalol undergoes extensive metabolic changes in the gut and liver (MacCarthy and Bloomfield, 1983). Glucuronidation, mainly by UGT1A1 and UGT2B7, is the primary pathway of labetalol elimination (Jeong et al., 2008). The drug is metabolized by the UDP glucuronosyltransferases into two pharmacologically inactive metabolites, alcoholic glucuronide, and o-phenyl glucuronide (MacCarthy and Bloomfield, 1983). The metabolism of these drugs can be potentially influenced by HMs concurrently taken by pregnant women with or without clinician's permission.

Pregnant women may use HMs as complementary or alternative medicine to reduce their blood pressure. Many women taking HMs see them as a less-toxic natural alternative to prescription drugs. Therefore, they may consider taking Rauwolfia [Rauvolfia serpentina (L.) Benth. ex Kurz], buchu [Agathosma betulina (P.J.Bergius) Pillans], garlic (A. sativum L.), black or green tea [C. sinensis (L.) Kuntze], or Roselle (Hibiscus sabdariffa L.), hypertensive HMs (Tabassum and Ahmad, 2011; Lobay, 2015). For many of HMs, antihypertensive properties were established in animal models (Tabassum and Ahmad, 2011). Rauwolfia is a wellknown HM used for the treatment of hypertension (Lobay, 2015). Reserpine isolated from this herb was approved and use as a conventional drug for hypertension treatment. Currently, rauwolfia extracts may be used as adjunct therapy to the prescription medication (Lobay, 2015). Below we discuss potential interactions of $\mathrm{HMs}$ with prescription drugs used for the treatment of hypertension in pregnant women (Table 3).

An in vitro study conducted by Flynn et al. demonstrated that rauwolfia extract and plant alkaloids may inhibit CYP3A4 activity (except yohimbine) and significantly increase glucuronosyltransferase activity (except corynanthine and reserpic acid) (Flynn and Vohra, 2018). However, clinical implications of this study are not known. It has been also shown that valerian can inhibit CYP3A4 and P-glycoprotein activities in preclinical studies (Lefebvre et al., 2004; Sprouse and van Breemen, 2016). However, CYP3A4 inhibition demonstrated in preclinical studies was not confirmed clinical studies (Sprouse and van Breemen, 2016). St. John's Wort is considered to be a potent enhancer of CYP3A4 in vitro (Hellum and Nilsen, 2008). This preclinical observation was confirmed by clinical trials (Sprouse and van Breemen, 2016). Moore L. et al. have found that St. John's Wort's extracts increased expression of CYP3A4 in human hepatocytes via activation of pregnane $\mathrm{X}$ receptors (Moore et al., 2000). Green and black leisure teas were capable of inhibiting CYP3A4 enzyme activity in vitro (Tam et al., 2014; Sprouse and van Breemen, 2016). Ethanolic extract of hibiscus inhibited the activity of nine CYP450 enzymes including CYP3A4 (Johnson et al., 2013). Nevertheless, interactions of leisure teas and ethanolic hibiscus extract with drugs metabolized 
TABLE 3 | Potential HM interactions with conventional antihypertensive drugs taken by pregnant women.

\begin{tabular}{|c|c|c|c|}
\hline $\begin{array}{l}\text { Conventional } \\
\text { drugs }\end{array}$ & $\begin{array}{l}\text { Conventional drug } \\
\text { metabolism }\end{array}$ & Herbal medicine & HM potential effect on the conventional drug metabolism \\
\hline \multirow[t]{6}{*}{ Nifedipine } & CYP3A4 & Rauvolfia serpentina (L.) Benth. ex Kurz & $\downarrow$ CYP3A4 (Flynn and Vohra, 2018), clinical implications not known \\
\hline & & $\begin{array}{l}\text { Valeriana officinalis } \mathrm{L} \text {, } \\
\text { Camellia sinensis }(\mathrm{L} .) \text { Kuntze, } \\
\text { Hibiscus sabdariffa L. }\end{array}$ & $\begin{array}{l}\downarrow \text { CYP3A4 (Lefebvre et al., 2004; Johnson et al., 2013; Tam et al., } \\
\text { 2014; Sprouse and van Breemen, 2016) Insignificant herb-drug } \\
\text { interaction in humans }\end{array}$ \\
\hline & & Hypericum perforatum L., & $\begin{array}{l}\uparrow \text { CYP3A4 (Henderson et al., 2002; Hellum and Nilsen, 2008; Sprouse } \\
\text { and van Breemen, 2016) Confirmed in preclinical and clinical studies }\end{array}$ \\
\hline & & Ginkgo biloba L. & $\begin{array}{l}\text { No significant changes PK parameters in volunteers. Atypical 2-fold } \\
\text { increase plasma concentrations in } 2 \text { patients (Yoshioka et al., 2004). }\end{array}$ \\
\hline & & Silybum marianum (L.) Gaertn. & Not potent inhibitor of CYP3A4 in humans (Fuhr et al., 2007). \\
\hline & & Grapefruit juice & May inhibit metabolism and gastric emptying (Odou et al., 2005). \\
\hline Labetalol & UGT1A1 UGT2B7 & $\begin{array}{l}\text { Panax spp. Echinacea spp. Silybum marianum } \\
\text { (L.) Gaertn. Valeriana officinalis L. Camellia } \\
\text { sinensis (L.) Kuntze }\end{array}$ & $\downarrow$ UGT1A1 (Mohamed et al., 2010), clinical implications not known \\
\hline
\end{tabular}

by CYP3A4 were considered to be clinically irrelevant herb-drug interactions (Donovan et al., 2004; Gurley et al., 2005; Hellum and Nilsen, 2008; Johnson et al., 2013).

Concurrent administration of an extract of ginkgo leaves with nifedipine in rats increased the area under the concentrationtime curve and the absolute bioavailability of nifedipine, demonstrating the potential interactions with nifedipine in rats (Yoshioka et al., 2004). Concurrent administration of ginkgo with nifedipine to volunteers did not change significantly pharmacokinetic parameters of nifedipine (Yoshioka et al., 2004). However, two subjects had significantly increased levels of plasma nifedipine, severe long lasting headaches, and hot flushes. Authors have concluded that ginkgo and nifedipine should not be used concurrently (Yoshioka et al., 2004). An in vitro studies have demonstrated that bioactive constituents present in milk thistle [Silybum marianum (L.) Gaertn.] extract inhibited CYP3A4 enzyme (Fuhr et al., 2007). Simultaneous administration of milk thistle extract with nifedipine to human volunteers did not significantly change the metabolism of nifedipine. Some tendency to delayed absorption of the drug was observed. It has been concluded that milk thistle is not potent inhibitor of CYP3A4 inhibitor in humans (Fuhr et al., 2007). Grapefruit (Citrus $\times$ paradisi Macfad.) juice taken with nifedipine can inhibit drug metabolism and delay gastric emptying (Odou et al., 2005).

According to Mohamed et al. several HMs can inhibit UGT1A1 activity, specifically ginseng (Panax spp.), coneflower (Echinacea spp.), milk thistle (S. marianum L.), valerian ( $V$. officinalis L.), and green tea epigallocatechin gallate (Mohamed et al., 2010). These herbs, when concurrently taken with labetalol, can potentially interfere with its metabolism.

In summary, hypertension occurring during pregnancy is a serious condition that may result in life-threatening complications. There is not enough evidence to conclude that medicinal herbs that women can consume during pregnancy will have a clinically meaningful effect on the pharmacokinetics and pharmacodynamics of anti-hypertensive medications. Based on the currently available data, we believe that concurrent use of labetalol and nifedipine with HMs in recommended doses would not alter metabolism of conventional drugs. However, many consumers consider HMs as a safe alternative to the conventional drugs and may exceed recommended HM doses. In this situation, the concurrent use of HM may complicate treatment of hypertension in pregnancy. The most alarming is the clinically proven interaction of nifedipine with St. John's Wort. Therefore, healthcare professionals should discuss with their patients potential risks of the concomitant use of anti-hypertensive drugs and herbal supplements.

\section{Asthma in Pregnancy and HM Use}

Asthma is a disorder defined by the inflammatory narrowing of the bronchial tubes of the lungs and is the most common chronic condition associated with pregnancy (Murphy and Schatz, 2014), affecting an estimated $4 \%-8 \%$ of pregnant women (National Heart Lung et al., 2005). Poor asthma control during pregnancy is associated with adverse maternal outcomes (e.g., hypertension, gestational diabetes, preterm delivery, maternal mortality) and neonatal outcomes (e.g., congenital malformation, hospitalization, and death) (Murphy and Schatz, 2014; Baghlaf et al., 2017; McLaughlin et al., 2018). The U.S. Department of Health and Human Services recommendations prioritize asthma control over possible pharmaceutic side effects related to pregnancy (National Heart Lung et al., 2005), as it has been shown that effective perinatal control of asthma has been associated with improved outcomes for both mother and infant (Ibrahim et al., 2018; Murphy and Schatz, 2014; Al Ghobain et al., 2018; McLaughlin et al., 2018).

Asthma therapy during pregnancy is mainly aimed at maintaining airways, reducing the use of short-acting inhaled 
beta ${ }_{2}$-agonists, and reducing the risk of acute exacerbations to preserve oxygenation for both mother and offspring. Current asthma daily therapy commonly includes a short-acting beta $2^{-}$ agonist (e.g., albuterol) and depending on severity, an inhaled corticosteroid (e.g., fluticasone, budesonide, beclomethasone, or mometasone), a long-acting beta-agonist (e.g., salmeterol, formoterol), or a leukotriene receptor antagonist (e.g., montelukast, zafirlukast). Additional medications may include systemic corticosteroids (e.g., prednisone, prednisolone, or methylprednisolone), a 5-lipoxygenase inhibitor (e.g., zileuton), an immunomodulator (Omalizumab), cromolyn, or a methylxanthine (e.g., theophylline) (National Heart Lung et al., 2005; Namazy and Schatz, 2018).

Despite evidence suggesting improved outcomes for both mother and offspring, women will often alter or stop their asthma treatment regimen. Recently, (Ibrahim et al., 2018; Ghobain et al., 2018) have reported that over half of women have uncontrolled asthma during their pregnancy and that $40 \%-$ $50 \%$ of women believe that asthma medications, corticosteroids, in particular, will be more harmful to their offspring than uncontrolled asthma. Conceivably, these women could be supplementing with HMs and dietary supplements to help control their asthma symptoms, ameliorate discomfort associated with pregnancy, or improve general health.

Depending on the metabolic paths of these medications, HMs may result in unintended patient consequences (Table 4); however, at present, the clinical significance of herb-drug interactions associated with asthma medications is generally unknown. Of particular importance are inhaled corticosteroids (e.g. budesonide [AstraZeneca, 2006], mometasone [Merck Sharp and Dohme Corp, 2018] fluticasone [GlaxoSmithKline, 2017] beclomethasone [Teva Respiratory, 2017], and corticosteroids (e.g., prednisolone, methylprednisolone) [Bergmann et al., 2012; Pfizer, 2018]+, which are foundational treatment for asthma, are undergo significant metabolism by CYP3A4. Montelukast is another example where herbal supplementation may lead to unintended affects. Montelukast is metabolized by CYP2C8 as well as CYP3A4 at clinically relevant concentrations [Merck Sharp and Dohme Corp, 2016].

Several HMs have been evaluated for roles in asthma control. For example, flavonoids, such as Sophora flavescens Aiton (Yang et al., 2013) and Glycyrrhiza uralensis Fisch. ex DC. (Yang et al., 2013), have been implicated in the possible prevention of asthma symptoms (Tanaka and Takahashi, 2013) and to possibly reduce the risk of asthma in infants born to mothers with asthma (LopezExposito et al., 2015). Similarly, Angelica dahurica (Hoffm.) Benth. \& Hook.f. ex Franch. \& Sav. root extract (Lee et al., 2011) and green tea (C. sinensis (L.) Kuntze) (Yang et al., 2018), have been implicated with anti-asthmatic effects and reduction in asthma-related inflammation, respectively. Eucalyptus oil has also been used for respiratory indications (Ahmed et al., 2017) and it is reported that cineole is associated with improved lung function (Worth and Dethlefsen, 2012). These and other such observations may encourage pregnant women to replace or supplement diet and asthma treatment regimens, despite known interactions with conventional drugs (Smeriglio et al., 2014).

Epigallocatechin gallate, a constituent of teas, has shown in vitro inhibition of Cytochrome $\mathrm{P} 450$ enzymes, including CYP1A2, CYP2C8, CYP2C9, and CYP3A4 (Albassam and Markowitz, 2017) and therefore has potential effects on the majority of conventional asthma drugs. Similarly, eucalyptus oil (Eucalyptus globulus Labill.) was shown in vitro to inhibit CYP3A4 (Unger and Frank, 2004). Recently, epigallocatechin gallate was implicated in increasing the systemic half-life of Montelukast (Misaka et al., 2013). A. dahurica (Hoffm.) Benth. \& Hook.f. ex Franch. \& Sav. has been associated with inhibition of CYP3A, as well as CYP2C and CYP2D1 (Ishihara et al., 2000), which may reduce systemic elimination of corticosteroids.

As described in the previous sections, St. John's Wort is a significant CYP3A4 inducer and therefore may reduce

TABLE 4 | Potential HM interactions with conventional asthma control drugs taken by pregnant women.

\begin{tabular}{|c|c|c|c|}
\hline Conventional drug & $\begin{array}{l}\text { Conventional drug } \\
\text { metabolism }\end{array}$ & Herbal medicine & Potential effect \\
\hline
\end{tabular}

Corticosteroids CYP3A4 Trachyspermum ammi (L) Sprague

(e.g. Fluticasone,

Budesonide,

Beclomethasone,

Prednisone,

Prednisolone)

Montelukast

$\begin{array}{ll}\text { OATP2B1 substrate } & \text { Orange juice } \\ \text { CYP3A4 } & \text { Grapefruit juice } \\ & \text { Eucalyptus globulus Labill. } \\ & \text { Epigallocatechin gallate } \\ \text { St. John's Wort }\end{array}$

Angelica dahurica (Hoffm.) Benth. \& Hook.f. ex Franch. \& Sav

Eucalyptus globulus Labill.

St. John's Wort

St. John's Wort
CYP3A4 inhibitor and blood thinner (Bairwa et al., 2012)

CYP3A4 inhibitor (Ishihara et al., 2000)

CYP3A4 inhibitor (Unger and Frank, 2004)

CYP 3A4 inducer (Henderson et al., 2002)

$\downarrow$ AUC (SLCO2B1 C.935G/G homozygote) (Mougey et al., 2011; Chen et al., 2018)

$\uparrow$ AUC (Cingi et al., 2013)

CYP3A4 inhibitor (Unger and Frank, 2004)

Extension of systemic half-life (Misaka et al., 2013)

CYP 3A4 inducer

(Komoroski et al., 2004) 
concentrations of both corticosteroids and Montelukast. Pregnant women may also take the antioxidants vitamins $C$, found in a variety of citrus fruits including grapefruit. Grapefruit is a known inhibitor of CYP3A4 (Mouly et al., 2017) and therefore may interact with glucocorticoids increase systemic exposure. Carum Ajowan [Trachyspermum ammi (L.) Sprague] may also be taken orally by pregnant women to treat indigestion or asthma (Bairwa et al., 2012). Ajowan (Carum copticum L) is a CYP3A4 inhibitor (Di Minno et al., 2017). Similar to grapefruit it may increase systemic exposure to glucocorticoids. Unripe ajwain contains chromone, a constituent with anticoagulant properties (Boskabady et al., 2014). Use of this herb by pregnant women may result in an excessive bleeding during cesarean section or labor. Montelukast also undergoes carrier mediated transport by OATP2B1. There is some evidence to suggest that grapefruit juice (Cingi et al., 2013), a known CYP3A4 inhibitor, increases montelukast exposure while orange juice (Mougey et al., 2011; Chen et al., 2018) decreases montelukast exposure in individuals with specific OATP2B1 variations (e.g. SLCO2B1 c.935G/G).

Poorly controlled asthma during pregnancy is of serious health concern for both mother and offspring, resulting in increased morbidity and mortality. Pregnant women may be supplementing or replacing prescribed conventional drugs with medicinal herbs and dietary supplements. Definitive research into the clinical implications for potential asthma herb-drug interactions has not been completed; however, metabolism of conventional drugs and HMs are often regulated by Cytochrome P450 enzymes [e.g., CYP3A4 (AstraZeneca, 2006; Bergmann et al., 2012; Rajapakse et al., 2016; GlaxoSmithKline, 2017; Teva Respiratory, 2017; Merck Sharp and Dohme Corp, 2018; Pfizer, 2018, CYP2C8 (Yang et al., 2018), CYP2C9 (DEY, 2007; Cornerstone Therapeutics Inc, 2012; AstraZeneca Pharmaceuticals, 2013, CYP2C19 (DEY, 2007), CYP1A2 (Cornerstone Therapeutics Inc, 2012), etc.] or have potential additive effects (Table 3). The clinical significance of these observations requires additional study; however, clinicians should be aware of the concurrent use of asthma-related drugs and herbal/dietary supplements, which may complicate treatment. The authors do not recommend replacement or unmonitored supplementations. The authors do recommend monitoring, further retrospective analyses, and continued education of and discussion with patients, clinicians, and scientists.

\section{SUMMARY}

As outlined in this review, the problem has become the introduction of HMs or other natural products similtaneously with conventional drugs during pregnancy and our lack of knowledge of potential herbal-drug interactions, which can impact fetus or mother. Pregnant women often consume HMs without consulting their healthcare providers. There are many known benefits associated with HMs that can help during or after pregnancy such as increasing milk production, decreasing nausea, easing labor pains, relief of morning sickness, or decreasing flatulence. Many women take HMs when they are pregnant without any concern based on the assumption that since herbals are natural, they do not have any worry that these products will cause harm to them or their unborn babies.

There is a desperate need for education to be provided to pregnant women and their healthcare professionals. We need to move away from the idea of HMs not being harmful. Even conventional drugs that can be bought over the counter have the potential to interact with HMs. For example, if pregnant women are taking aspirin as well as HMs that also have antiplatelet activity (El Haouari and Rosado, 2016), it can lead to an increased risk of bleeding and, in some pregnant women, this can become life threatening. This is an area, where there is limited research, and the use of HMs or potential interactions of these with conventional drugs can lead to unknown impacts on the fetus or cause severe complications to the mother. There is an urgent need for more attention to be paid to the safety of combining conventional drugs and HMs during pregnancy.

HMs and their preparations can potentially interact with conventional drugs reducing or increasing the efficacy of the drugs, and in some disease conditions (e.g., hypertension, asthma, epilepsy) this can lead to life-threatening situations. Due to the overall reluctance to undertake studies during pregnancy, we lack information and in many cases with do not know what the optimal therapeutic dose of a drug that should be given to a pregnant woman in her third trimester is. Without this foundational understanding, determining the optimal treatment may be further complicated if she is also taking an HM that reduces the efficacy of her conventional drugs.

Also, of concern is that the embryotoxic effects of HMs have been poorly studied. Clinical pharmacologists, scientists, and physicians need to be more informed regarding preclinical and clinical study findings of adverse effects related to HMs on the developing fetus.

In recent times, it has been recognized through the establishment of the $21^{\text {st }}$ Century Cures Act that there is a need to undertake research to answer questions that are specific in pregnant and lactating women (An Act: To accelerate the discovery, development, and delivery of 21 st century cures, and for other purposes). We are not yet at the point of initiating clinical trials to investigate herbal-drug interactions, but the establishment of the Task Force on Research Specific to Pregnant Women and Lactating Women (NIH, 2018) is a move in the right direction. Continued focus, discussion, and research by invested parties will be necessary as we move forward to addressing potential $\mathrm{HM}$ and HMdrug interaction safety concerns.

\section{AUTHOR CONTRIBUTIONS}

SI prepared materials and wrote the Introduction and Efficacy and Safety of HM Used by Pregnant Women sections. OA was responsible for materials of the Consumption of Herbal Medicines by Pregnant Women section. EE and LK prepared materials and wrote the Hypertension in Pregnancy and HM Use section. AB and AK were responsible for the Epilepsy in Pregnancy and HM Use section. KJ and VB wrote the Asthma in Pregnancy and Herbal Medicine Use section. CS summarized presented in the manuscript materials and wrote abstract and summary statement. 


\section{REFERENCES}

AstraZeneca LP. (2006). "PULMICORT TURBUHALER® $200 \mathrm{mcg}$ (budesonide inhalation powder): Leaflet." Retrieved 16 May 2018, from https://www. accessdata.fda.gov/drugsatfda_docs/label/2007/020441s020lbl.pdf

AstraZeneca Pharmaceuticals LP. (2013). "ACCOLATE® (zafirlukast) TABLETS: Patient information leaflet.” Retrieved 16 May 2018, from https://www. accessdata.fda.gov/drugsatfda_docs/label/2013/020547s033lbl.pdf

Adams, J., Lui, C. W., Sibbritt, D., Broom, A., Wardle, J., Homer, C., et al. (2009). Women's Use of Complementary and Alternative Medicine During Pregnancy: A Critical Review of the Literature. Birth-Iss Perinat C. 36 (3), 237-245. doi: 10.1111/ j.1523-536X.2009.00328.x

Adams, J. (2011). Growing popularity of complementary and alternative medicine during pregnancy and implications for healthcare providers. Expert Rev. Obstet. Gynecol. 4 (6), 365-366. doi: 10.1586/eog.11.29

Adusi-Poku, Y., Vanotoo, L., Detoh, E. K., Oduro, J., Nsiah, R. B., and Natogmah, A. Z. (2015). Type of herbal medicines utilized by pregnant women attending ante-natal clinic in Offinso North district: Are orthodox prescribers aware? Ghana Med. J. 49 (4), 227-232. doi: 10.4314/gmj.v49i4.2

Ahmed, M., Hwang, J. H., Choi, S., and Han, D. (2017). Safety classification of herbal medicines used among pregnant women in Asian countries: a systematic review. BMC Complement. Altern. Med. 17 (1), 489. doi: 10.1186/ s12906-017-1995-6

Al Ghobain, M. O., AlNemer, M., and Khan, M. (2018). Assessment of knowledge and education relating to asthma during pregnancy among women of childbearing age. Asthma Res. Pract. 4, 2. doi: 10.1186/s40733-017-0038-x

Al Saabi, A., Allorge, D., Sauvage, F. L., Tournel, G., Gaulier, J. M., Marquet, P., et al. (2013). Involvement of UDP-glucuronosyltransferases UGT1A9 and UGT2B7 in ethanol glucuronidation, and interactions with common drugs of abuse. Drug Metab. Dispos. 41 (3), 568-574. doi: 10.1124/dmd.112.047878

Albassam, A. A., and Markowitz, J. S. (2017). An Appraisal of Drug-Drug Interactions with Green Tea (Camellia sinensis). Planta Med. 83 (6), 496508. doi: 10.1055/s-0043-100934

Al-Ramahi, R., Jaradat, N., and Adawi, D. (2013). Use of herbal medicines during pregnancy in a group of Palestinian women. J. Ethnopharmacol. 150 (1), 79-84. doi: 10.1016/j.jep.2013.07.041

An Act: To accelerate the discovery, development, and delivery of 21st century cures, and for other purposes. Available at: https://www.congress.gov/114/ plaws/publ255/PLAW-114publ255.pdf. In: Congress U, ed. Public Law 114255. Washington DC (2016):312.

Baghlaf, H., Spence, A. R., Czuzoj-Shulman, N., and Abenhaim, H. A. (2017). Pregnancy outcomes among women with asthma. J. Matern. Fetal Neonatal. Med. 1-7. doi: 10.1080/14767058.2017.1404982

Bairwa, R., Sodha, R. S., and Rajawat, B. S. (2012). Trachyspermum ammi. Pharmacogn. Rev. 6 (11), 56-60. doi: 10.4103/0973-7847.95871

Barnes, J., McLachlan, A. J., Sherwin, C. M. T., and Enioutina, E. Y. (2016). Herbal Medicines: Challenges in the Modern World. Part 1 (Australia and New Zealand), Expert Rev. Clin. Pharmacol. 9 (7), 905-915. doi: 10.1586/17512433.2016.1171712

Bartels, A., and O'Donoghue, K. (2011). Cholesterol in pregnancy: a review of knowns and unknowns. Obstet. Med. 4 (4), 147-151. doi: 10.1258/om.2011.110003

Bergmann, T. K., Barraclough, K. A., Lee, K. J., and Staatz, C. E. (2012). Clinical pharmacokinetics and pharmacodynamics of prednisolone and prednisone in solid organ transplantation. Clin. Pharmacokinet. 51 (11), 711-741. doi: 10.1007/s40262-012-0007-8

Bhatt, P., Leong, T. K., Yadav, H., and Doshi, A. (2016). Prevalence and factors associated with the use of herbal medicines among women receiving antenatal care in hospitals-Mumbai, India. Int. J. Phytothery. 6 (2), 82-90.

Bhatt, A. (2016). Phytopharmaceuticals: A new drug class regulated in India. Perspect. Clin. Res. 7 (2), 59-61. doi: 10.4103/2229-3485.179435

Boskabady, M. H., Alitaneh, S., and Alavinezhad, A. (2014). Carum copticum L.: a herbal medicine with various pharmacological effects. BioMed. Res. Int. 2014, 569087. doi: 10.1155/2014/569087

Brookes, K. (2018). Chemical investigation of isihlambezo or traditional pregnancy related medicine. (University of Kwa-Zulu Nata; School of Laboratory Medicine and Medical Science, Physiology). Available at: http:hdl.handle.net/ $10413 / 6093$.

Burstein, A. H., Horton, R. L., Dunn, T., Alfaro, R. M., Piscitelli, S. C., and Theodore, W. (2000). Lack of effect of St John's Wort on carbamazepine pharmacokinetics in healthy volunteers. Clin. Pharmacol. Ther. 68 (6), 605612. doi: $10.1067 / \mathrm{mcp} .2000 .111530$

Chan, L. Y., Chiu, P. Y., and Lau, T. K. (2003). An in-vitro study of ginsenoside Rb1-induced teratogenicity using a whole rat embryo culture model. Hum. Reprod. 18 (10), 2166-2168. doi: 10.1093/humrep/deg401

Chen, M., Zhou, S. Y., Fabriaga, E., Zhang, P. H., and Zhou, Q. (2018). Fooddrug interactions precipitated by fruit juices other than grapefruit juice: An update review. J. Food Drug Anal. 26 (2S), S61-S71. doi: 10.1016/j.jfda.2018. 01.009

Chittumma, P., Kaewkiattikun, K., and Wiriyasiriwach, B. (2007). Comparison of the effectiveness of ginger and vitamin B6 for treatment of nausea and vomiting in early pregnancy: a randomized double-blind controlled trial. J. Med. Assoc. Thai. 90 (1), 15-20.

Chuang, C. H., Doyle, P., Wang, J. D., Chang, P. J., Lai, J. N., and Chen, P. C. (2006). Herbal medicines used during the first trimester and major congenital malformations: an analysis of data from a pregnancy cohort study. Drug Saf. 29 (6), 537-548. doi: 10.2165/00002018-200629060-00006

Chuang, C. H., Chang, P. J., Hsieh, W. S., Tsai, Y. J., Lin, S. J., and Chen, P. C. (2009). Chinese herbal medicine use in Taiwan during pregnancy and the postpartum period: a population-based cohort study. Int. J. Nurs. Stud. 46 (6), 787-795. doi: 10.1016/j.ijnurstu.2008.12.015

Cingi, C., Toros, S. Z., Gurbuz, M. K., Ince, I., Cakli, H., Erdogmus, N., et al. (2013). Effect of grapefruit juice on bioavailability of montelukast. Laryngoscope 123 (4), 816-819. doi: 10.1002/lary.23700

Committee on Obstetric P. (2017). Committee Opinion No. 692: Emergent Therapy for Acute-Onset, Severe Hypertension During Pregnancy and the Postpartum Period. Obstet. Gynecol. 129 (4), e90-e95. doi: 10.1097/ AOG.0000000000002019

Cornerstone Therapeutics Inc (2012). "ZYFLO® (zileuton tablets): Package insert." Retrieved 16 May 2018, from https://www.accessdata.fda.gov/ drugsatfda_docs/label/2012/020471s017lbl.pdf

Dante, G., Pedrielli, G., Annessi, E., and Facchinetti, F. (2013). Herb remedies during pregnancy: a systematic review of controlled clinical trials. J. Matern. Fetal Neonatal. Med. 26 (3), 306-312. doi: 10.3109/14767058.2012.722732

DEY. (2007). "PERFOROMIST (formoterol fumarate) Inhalation Solution: Medication guide." Retrieved 16 May 2018, from https://www.accessdata.fda. gov/drugsatfda_docs/label/2007/022007lbl.pdf

Di Minno, A., Frigerio, B., Spadarella, G., Ravani, A., Sansaro, D., Amato, M., et al. (2017). Old and new oral anticoagulants: Food, herbal medicines and drug interactions. Blood Rev. 31 (4), 193-203. doi: 10.1016/j.blre.2017.02.001

Dika, H., Dismas, M., Iddi, S., and Rumanyika, R. (2017). Prevalent use of herbs for the reduction of labor duration in Mwanza, Tanzania: are obstetricians aware? Tanzania J. Health Res. 19 (2): 1-8. doi: 10.4314/thrb.v19i2.5

Donovan, J. L., DeVane, C. L., Chavin, K. D., Wang, J. S., Gibson, B. B., Gefroh, H. A., et al. (2004). Multiple night-time doses of valerian (Valeriana officinalis) had minimal effects on CYP3A4 activity and no effect on CYP2D6 activity in healthy volunteers. Drug Metab. Dispos. 32 (12), 1333-1336. doi: 10.1124/ dmd.104.001164

Dugoua, J. J., Mills, E., Perri, D., and Koren, G. (2006). Safety and efficacy of ginkgo (Ginkgo biloba) during pregnancy and lactation. Can. J. Clin. Pharmacol. 13 (3), e277-e284.

Dugoua, J. J., Perri, D., Seely, D., Mills, E., and Koren, G. (2008). Safety and efficacy of blue cohosh (Caulophyllum thalictroides) during pregnancy and lactation. Can. J. Clin. Pharmacol. 15 (1), e66-e73.

Dugoua, J. J. (2010). Herbal medicines and pregnancy. J. Popul. Ther. Clin. Pharmacol. 3 (17), e370-e378.

Durr, D., Stieger, B., Kullak-Ublick, G. A., Rentsch, K. M., Steinert, H. C., Meier, P. J., et al. (2000). St John's Wort induces intestinal P-glycoprotein/MDR1 and intestinal and hepatic CYP3A4. Clin. Pharmacol. Ther. 68 (6), 598-604. doi: $10.1067 / \mathrm{mcp} .2000 .112240$

El Haouari, M., and Rosado, J. A. (2016). Medicinal Plants with Antiplatelet Activity. Phytother. Res. 30 (7), 1059-1071. doi: 10.1002/ptr.5619

Elkhoudri, N., Baali, A., and Amor, H. (2016). Maternal morbidity and the use of medicinal herbs in the city of Marrakech, Morocco. Indian J. Tradit. Knowledge 15 (1), 79-85.

Enioutina, E. Y., Salis, E. R., Job, K. M., Gubarev, M. I., Krepkova, L. V., and Sherwin, C. M. (2017). Herbal Medicines: challenges in the modern world. Part 5. status and current directions of complementary and alternative herbal 
medicine worldwide. Expert Rev. Clin. Pharmacol. 10 (3), 327-338. doi: 10.1080/17512433.2017.1268917

Ensiyeh, J., and Sakineh, M. A. (2009). Comparing ginger and vitamin B6 for the treatment of nausea and vomiting in pregnancy: a randomised controlled trial. Midwifery 25 (6), 649-653. doi: 10.1016/j.midw.2007.10.013

Fessenden, J. M., Wittenborn, W., and Clarke, L. (2001). Gingko biloba: a case report of herbal medicine and bleeding postoperatively from a laparoscopic cholecystectomy. Am. Surg. 67 (1), 33-35.

Fischer-Rasmussen, W., Kjaer, S. K., Dahl, C., and Asping, U. (1991). Ginger treatment of hyperemesis gravidarum. Eur. J. Obstet. Gynecol. Reprod. Biol. 38 (1), 19-24. doi: 10.1016/0028-2243(91)90202-V

Flynn, T. J., and Vohra, S. N. (2018). Simultaneous determination of intestinal permeability and potential drug interactions of complex mixtures using Caco2 cells and high-resolution mass spectrometry: Studies with Rauwolfia serpentina extract. Chemico-Biol. Inter. 290, 37-43. doi: 10.1016/ j.cbi.2018.05.006

Forster, D. A., Denning, A., Wills, G., Bolger, M., and McCarthy, E. (2006). Herbal medicine use during pregnancy in a group of Australian women. BMC Pregnancy Childbirth 6, 21. doi: 10.1186/1471-2393-6-21

Frawley, J., Adams, J., Sibbritt, D., Steel, A., Broom, A., and Gallois, C. (2013). Prevalence and determinants of complementary and alternative medicine use during pregnancy: results from a nationally representative sample of Australian pregnant women. Aust. N. Z. J. Obstet. Gynaecol. 53 (4), 347-352. doi: 10.1111/ ajo.12056

Frawley, J., Adams, J., Steel, A., Broom, A., Gallois, C., and Sibbritt, D. (2015). Women's use and self-prescription of herbal medicine during pregnancy: an examination of 1,835 Pregnant Women. Women's Health Issues 25 (4), 396402. doi: 10.1016/j.whi.2015.03.001

Fuhr, U., Beckmann-Knopp, S., Jetter, A., Luck, H., and Mengs, U. (2007). The effect of silymarin on oral nifedipine pharmacokinetics. Planta Med. 73 (14), 1429-1435. doi: 10.1055/s-2007-990256

Gaston, T. E., Bebin, E. M., Cutter, G. R., Liu, Y., Szaflarski, J. P., and Program, U. C. (2017). Interactions between cannabidiol and commonly used antiepileptic drugs. Epilepsia 58 (9), 1586-1592. doi: 10.1111/epi.13852

GlaxoSmithKline. (2017). "FLOVENT HFA (fluticasone propionate) inhalation aerosol, for oral inhalation: highlights of prescribing information." Retrieved 16 May 2018, from (2017). https://www.accessdata.fda.gov/drugsatfda_docs/ label/2017/021433s033lbl.pdf

Grush, L. R., Nierenberg, A., Keefe, B., and Cohen, L. S. (1998). St John's wort during pregnancy. JAMA 280 (18), 1566. doi: 10.1001/jama.280.18.1566

Gunn, J. K., Rosales, C. B., Center, K. E., Nunez, A., Gibson, S. J., Christ, C., et al. (2016). Prenatal exposure to cannabis and maternal and child health outcomes: a systematic review and meta-analysis. BMJ Open 6 (4), e009986. doi: 10.1136/bmjopen-2015-009986

Gurley, B. J., Gardner, S. F., Hubbard, M. A., Williams, D. K., Gentry, W. B., Khan, I. A., et al. (2005). In vivo effects of goldenseal, kava kava, black cohosh, and valerian on human cytochrome P450 1A2, 2D6, 2E1, and 3A4/5 phenotypes. Clin. Pharmacol. Ther. 77 (5), 415-426. doi: 10.1016/j.clpt. 2005.01.009

Hall, H. G., Griffiths, D. L., and McKenna, L. G. (2011). The use of complementary and alternative medicine by pregnant women: A literature review. Midwifery 27 (6), 817-824. doi: 10.1016/j.midw.2010.08.007

Hashiguchi, M., Ohta, Y., Shimizu, M., Maruyama, J., and Mochizuki, M. (2015). Meta-analysis of the efficacy and safety of Ginkgo biloba extract for the treatment of dementia. J. Pharm. Health Care Sci. 1, 14. doi: 10.1186/ s40780-015-0014-7

Hellum, B. H., and Nilsen, O. G. (2008). In vitro inhibition of CYP3A4 metabolism and P-glycoprotein-mediated transport by trade herbal products. Basic Clin. Pharmacol. Toxicol. 102 (5), 466-475. doi: 10.1111/j. 1742-7843.2008.00227.x

Henderson, L., Yue, Q. Y., Bergquist, C., Gerden, B., and Arlett, P. (2002). St John's wort (Hypericum perforatum): drug interactions and clinical outcomes. Br. J. Clin. Pharmacol. 54 (4), 349-356. doi: 10.1046/j.1365-2125.2002.01683.x

HIGHLIGHTS OF PRESCRIBING INFORMATION. EPIDIOLEX® (cannabidiol) oral solution, CX [pending DEA scheduling action]; available at: https://www.accessdata.fda.gov/drugsatfda_docs/label/2018/210365lbl.pdf. In: FDA, ed2018.
Holst, L., Nordeng, H., and Haavik, S. (2008). Use of herbal drugs during early pregnancy in relation to maternal characteristics and pregnancy outcome. Pharmacoepidem S. 17 (2), 151-159. doi: 10.1002/pds.1527

Holst, L., Wright, D., Haavik, S., and Nordeng, H. (2011). Safety and efficacy of herbal remedies in obstetrics-review and clinical implications. Midwifery 27 (1), 80-86. doi: 10.1016/j.midw.2009.05.010

Ibrahim, W. H., Rasul, F., Ahmad, M., Bajwa, A. S., Alamlih, L. I., El Arabi, A. M., et al. (2018). Asthma knowledge, care, and outcome during pregnancy: The QAKCOP study. Chron. Respir. Dis., 1479972318767719. doi: 10.1177/ 1479972318767719

Ishihara, K., Kushida, H., Yuzurihara, M., Wakui, Y., Yanagisawa, T., Kamei, H., et al. (2000). Interaction of drugs and Chinese herbs: pharmacokinetic changes of tolbutamide and diazepam caused by extract of Angelica dahurica. J. Pharm. Pharmacol. 52 (8), 1023-1029. doi: 10.1211/0022357001774750

Jeong, H., Choi, S., Song, J. W., Chen, H., and Fischer, J. H. (2008). Regulation of UDP-glucuronosyltransferase (UGT) $1 \mathrm{~A} 1$ by progesterone and its impact on labetalol elimination. Xenobiotica 38 (1), 62-75. doi: 10.1080/ 00498250701744633

Jepson, R. G., and Craig, J. C. (2008). Cranberries for preventing urinary tract infections. Cochrane Database Syst. Rev. (1), CD001321. doi: 10.1002/ 14651858.CD001321.pub4

Jo, J., Lee, S. H., Lee, J. M., Lee, H., Kwack, S. J., and Kim, D. I. (2016). Use and safety of Korean herbal medicine during pregnancy: a Korean medicine literature review. Eur. J. Integr. Med. 8 (1), 4-11. doi: 10.1016/j.eujim.2015.10.008

John, L. J., and Shantakumari, N. (2015). Herbal medicines use during pregnancy: a Review from the Middle East. Oman Med. J. 30 (4), 229-236. doi: 10.5001/ omj. 2015.48

Johnson, S. S., Oyelola, F. T., Ari, T., and Juho, H. (2013). In vitro inhibitory activities of the extract of Hibiscus sabdariffa L. (family Malvaceae) on selected cytochrome P450 isoforms. Afr. J. Tradit. Complement. Altern. Med. 10 (3), 533-540. doi: 10.4314/ajtcam.v10i3.22

Joulaeerad, N., Ozgoli, G., Hajimehdipoor, H., Ghasemi, E., and Salehimoghaddam, F. (2018). Effect of aromatherapy with peppermint oil on the severity of nausea and vomiting in pregnancy: a single-blind, randomized, placebo-controlled trial. J. Reprod. Infertil. 19 (1), 32-38.

Jurgens, T. M. (2003). Potential toxicities of herbal therapies in the developing fetus. Birth Defects Res. B. Dev. Reprod. Toxicol. 68 (6), 496-498. doi: 10.1002/ bdrb. 10050

Kanowski, S., Herrmann, W. M., Stephan, K., Wierich, W., and Horr, R. (1996). Proof of efficacy of the ginkgo biloba special extract EGb 761 in outpatients suffering from mild to moderate primary degenerative dementia of the Alzheimer type or multi-infarct dementia. Pharmacopsychiatry 29 (2), 4756. doi: $10.1055 / \mathrm{s}-2007-979544$

Kasper, S. (1997). Treatment of seasonal affective disorder (SAD) with hypericum extract. Pharmacopsychiatry 30 Suppl 2, 89-93. doi: 10.1055/s-2007-979526

Kast, R. E. (2001). Borage oil reduction of rheumatoid arthritis activity may be mediated by increased cAMP that suppresses tumor necrosis factor-alpha. Int. Immunopharmacol. 1 (12), 2197-2199. doi: 10.1016/S1567-5769(01)00146-1

Keating, A., and Chez, R. A. (2002). Ginger syrup as an antiemetic in early pregnancy. Altern. Ther. Health Med. 8 (5), 89-91.

Kennedy, D. A., Lupattelli, A., Koren, G., and Nordeng, H. (2013). Herbal medicine use in pregnancy: results of a multinational study. BMC Complem. Altern. M. 13 (355), 1-10. doi: 10.1186/1472-6882-13-355

Kennedy, D. A., Lupattelli, A., Koren, G., and Nordeng, H. (2016). Safety classification of herbal medicines used in pregnancy in a multinational study. BMC Complement. Altern. Med. 16, 102. doi: 10.1186/s12906-016-1079-z

Kim, H. L., Streltzer, J., and Goebert, D. (1999). St. John's wort for depression: a meta-analysis of well-defined clinical trials. J. Nerv. Ment. Dis. 187 (9), 532538. doi: 10.1097/00005053-199909000-00002

Kohnen, R., and Oswald, W. D. (1988). The effects of valerian, propranolol, and their combination on activation, performance, and mood of healthy volunteers under social stress conditions. Pharmacopsychiatry 21 (6), 447-448. doi: 10.1055/s-2007-1017047

Komoroski, B. J., Zhang, S., Cai, H., Hutzler, J. M., Frye, R., Tracy, T. S., et al. (2004). Induction and inhibition of cytochromes $\mathrm{P} 450$ by the St. John's wort constituent hyperforin in human hepatocyte cultures. Drug Metab. Dispos. 32 (5), 512-518. doi: $10.1124 / \mathrm{dmd} .32 .5 .512$ 
Krepkova, L. V., Savinova, T. B., Bortnikova, V. V., Borovkova, M. V., Dmitrieva, O. P., and Sidel'nikov, N. I. (2016). The effect of thermopsis. (thermopsis lanceolata R. BR.) dry extract on the embryogenesis of rats. Problems Biol. Med. Pharmaceut. Chem. 1, 8-12.

Kwon, H. L., Triche, E. W., Belanger, K., and Bracken, M. B. (2006). The epidemiology of asthma during pregnancy: prevalence, diagnosis, and symptoms. Immunol. Allergy Clin. North Am. 26 (1), 29-62. doi: 10.1016/j.iac.2005.11.002

Lai, C., Coulter, S. A., and Woodruff, A. (2017). Hypertension and pregnancy. Tex. Heart Inst. J. 44 (5), 350-351. doi: 10.14503/THIJ-17-6359

Lapi, F., Vannacci, A., Moschini, M., Cipollini, F., Morsuillo, M., Gallo, E., et al. (2010). Use, attitudes and knowledge of complementary and alternative drugs (CADs) among pregnant women: a preliminary survey in Tuscany. Evid. Based Complement. Alternat. Med. 4 (7), 477-486. doi: 10.1093/ecam/nen031

Lee, M. Y., Seo, C. S., Lee, J. A., Lee, N. H., Kim, J. H., Ha, H., et al. (2011). Antiasthmatic effects of Angelica dahurica against ovalbumin-induced airway inflammation via upregulation of heme oxygenase-1. Food Chem. Toxicol. 49 (4), 829-837. doi: 10.1016/j.fct.2010.12.004

Lefebvre, T., Foster, B. C., Drouin, C. E., Krantis, A., Livesey, J. F., and Jordan, S. A. (2004). In vitro activity of commercial valerian root extracts against human cytochrome P450 3A4. J. Pharm. Pharm. Sci. 7 (2), 265-273.

Leung, K. Y., Lee, Y. P., Chan, H. Y., Lee, C. P., and Tang, M. H. (2002). Are herbal medicinal products less teratogenic than Western pharmaceutical products. Acta Pharmacol. Sin. 23 (12), 1169-1172.

Linde, K., and Mulrow, C. D. (2000). St John's wort for depression. Cochrane Database Syst. Rev. (2), CD000448. doi: 10.1002/14651858.CD000448

Linde, K., Ramirez, G., Mulrow, C. D., Pauls, A., Weidenhammer, W., and Melchart, D. (1996). St John's wort for depression-an overview and metaanalysis of randomised clinical trials. BMJ 313 (7052), 253-258. doi: 10.1136/ bmj.313.7052.253

Liu, W., Ge, T., Pan, Z., Leng, Y., Lv, J., and Li, B. (2017). The effects of herbal medicine on epilepsy. Oncotarget 8 (29), 48385-48397. doi: 10.18632/oncotarget.16801

Lobay, D. (2015). Rauwolfia in the Treatment of Hypertension. Integr. Med. (Encinitas) 14 (3), 40-46.

Lopez-Exposito, I., Srivastava, K. D., Birmingham, N., Castillo, A., Miller, R. L., and Li, X. M. (2015). Maternal antiasthma simplified herbal medicine intervention therapy prevents airway inflammation and modulates pulmonary innate immune responses in young offspring mice. Ann. Allergy Asthma Immunol. 114 (1), 43-51e1 doi: 10.1016/j.anai.2014.10.018

Louik, C., Gardiner, P., Kelley, K., and Mitchell, A. (2010). Use of herbal treatments in pregnancy. Am. J. Obstet. Gynecol. 5 (202), 439.e431-439. doi: 10.1016/j.ajog.2010.01.055

Low Dog, T. (2009). The use of botanicals during pregnancy and lactation. Altern. Ther. Health Med. 15 (1), 54-58. doi: 10.1089/act.2009.15209

Mabina, M. H., Pitsoe, S. B., and Moodley, J. (1997). The effect of traditional herbal medicines on pregnancy outcome. The King Edward VIII Hospital experience. S. Afr. Med. J. 87 (8), 1008-1010.

MacCarthy, E. P., and Bloomfield, S. S. (1983). Labetalol: a review of its pharmacology, pharmacokinetics, clinical uses and adverse effects. Pharmacotherapy 3 (4), 193-219. doi: 10.1002/j.1875-9114.1983.tb03252.x

Mahmoudian, A., Rajaei, Z., Haghir, H., Banihashemian, S., and Hami, J. (2012). Effects of valerian consumption during pregnancy on cortical volume and the levels of zinc and copper in the brain tissue of mouse fetus. Zhong Xi Yi Jie He Xue Bao. 10 (4), 424-429. doi: 10.3736/jcim20120411

Maliwichi-Nyirenda, C. P., and Maliwichi, L. L. (2010). Medicinal plants used to induce labor and traditional techniques used in determination of onset of labor in pregnant women in Malawi: a case study of Mulanje district. J. Med. Plants Res. 4 (24), 2609-2614.

Maputle, S. M., Mothiba, T. M., and Maliwichi, L. (2015). Traditional medicine and pregnancy management: perceptions of traditional health practitioners in Capricorn district, Limpopo Province. Stud. Ethno-Med. 9 (1), 67-75. doi: 10.1080/09735070.2015.11905422

Markowitz, J. S., Donovan, J. L., DeVane, C. L., Taylor, R. M., Ruan, Y., Wang, J. S., et al. (2003). Effect of St John's wort on drug metabolism by induction of cytochrome P450 3A4 enzyme. JAMA 290 (11), 1500-1504. doi: 10.1001/ jama.290.11.1500

Martinez, B., Kasper, S., Ruhrmann, S., and Moller, H. J. (1994). Hypericum in the treatment of seasonal affective disorders. J. Geriatr. Psychiatry Neurol. 7 Suppl 1, S29-S33. doi: 10.1177/089198879400701s09
McLaughlin, K., Foureur, M., Jensen, M. E., and Murphy, V. E. (2018). Review and appraisal of guidelines for the management of asthma during pregnancy. Women Birth. 31 (6), e349-e357. doi: 10.1016/j.wombi.2018.01.008

Merck Sharp and Dohme Corp. (2016).“SINGULAIR® (montelukast sodium) Tablets, Chewable Tablets, and Oral Granules: Highlights of prescribing information." from https://www.accessdata.fda.gov/drugsatfda_docs/label/ 2016/020829s069,020830s071,021409s047lbl.pdf.

Merck Sharp and Dohme Corp. (2018). "ASMANEX® HFA (mometasone furoate) inhalation aerosol, for oral inhalation use: Highlights of prescribing information." Retrieved 16 May 2018, from https://www.accessdata.fda.gov/ drugsatfda_docs/label/2018/205641s007s008lbl.pdf

Misaka, S., Kawabe, K., Onoue, S., Werba, J. P., Giroli, M., Tamaki, S., et al. (2013). Effects of green tea catechins on cytochrome P450 2B6, 2C8, 2C19, 2D6 and 3A activities in human liver and intestinal microsomes. Drug Metab. Pharmacokinet. 28 (3), 244-249. doi: 10.2133/dmpk.DMPK-12RG-101

Mohamed, M. F., Tseng, T., and Frye, R. F. (2010). Inhibitory effects of commonly used herbal extracts on UGT1A1 enzyme activity. Xenobiotica 40 (10), $663-$ 669. doi: $10.3109 / 00498254.2010 .505669$

Moore, L. B., Goodwin, B., Jones, S. A., Wisely, G. B., Serabjit-Singh, C. J., Willson, T. M., et al. (2000). St. John's wort induces hepatic drug metabolism through activation of the pregnane X receptor. Proc. Natl. Acad. Sci. U. S. A. 97 (13), 7500-7502. doi: 10.1073/pnas.130155097

Mougey, E. B., Lang, J. E., Wen, X., and Lima, J. J. (2011). Effect of citrus juice and SLCO2B1 genotype on the pharmacokinetics of montelukast. J. Clin. Pharmacol. 51 (5), 751-760. doi: 10.1177/0091270010374472

Mouly, S., Lloret-Linares, C., Sellier, P. O., Sene, D., and Bergmann, J. F. (2017). Is the clinical relevance of drug-food and drug-herb interactions limited to grapefruit juice and Saint-John's Wort? Pharmacol. Res. 118, 82-92. doi: 10.1016/j.phrs.2016.09.038

Moussally, K., Oraichi, D., and Bérard, A. (2009). Herbal products use during pregnancy: prevalence and predictors. Pharmacoepidemiol. Drug Saf. 6 (18), 454-461. doi: 10.1002/pds.1731

Mugomeri, E., Seliane, K., Chatanga, P., and Maibvise, C. (2015). Identifying promoters and reasons for medicinal herb usage during pregnancy in Maseru, Lesotho. Afr. J. Nurs. Midwifwery. 17 (1), 4-16. doi: 10.25159/2520-5293/63

Mureyi, D. D., Monera, T. G., and Maponga, C. C. (2012). Prevalence and patterns of prenatal use of traditional medicine among women at selected harare clinics: a cross-sectional study. BMC Complem. Altern. M. 12, 164. doi: 10.1186/14726882-12-164

Murphy, V. E., and Schatz, M. (2014). Asthma in pregnancy: a hit for two. Eur. Respir. Rev. 23 (131), 64-68. doi: 10.1183/09059180.00008313

Mustafa, R., Ahmed, S., Gupta, A., and Venuto, R. C. (2012). A comprehensive review of hypertension in pregnancy. J. Pregnancy 105918. doi: 10.1155/2012/ 105918

Naidu, M. (2014). Understanding African indigenous approaches to reproductive health: beliefs around traditional medicine. Stud. Ethno-Med. 8 (2), 147-156. doi: 10.1080/09735070.2014.11917629

Namazy, J. A., and Schatz, M. (2018). Management of asthma during pregnancy: optimizing outcomes and minimizing risk. Semin. Respir. Crit. Care Med. 39 (1), 29-35. doi: 10.1055/s-0037-1606216

National Heart Lung, Blood Institute, National Asthma Education, Prevention Program Asthma, Pregnancy Working Group. (2005). NAEPP expert panel report. Managing asthma during pregnancy: recommendations for pharmacologic treatment-2004 update. J. Allergy Clin. Immunol. 115 (1), 3446. doi: $10.1016 /$ j.jaci.2004.10.023

Nergard, C. S., Ho, T. P. T., Diallo, D., Ballo, N., Paulsen, B. S., and Nordeng, H. (2015). Attitudes and use of medicinal plants during pregnancy among women at health care centers in three regions of Mali, West-Africa. J. Ethnobiol. Ethnomed. 11, 73. doi: 10.1186/s13002-015-0057-8

NIH. (2018). Task Force on Research Specific to Pregnant Women and Lactating Women (PRGLAC); available at: https://www.nichd.nih.gov/About/Advisory/ PRGLAC. Accessed June 26.

Nordeng, H., and Havnen, G. C. (2004). Use of herbal drugs in pregnancy: a survey among 400 Norwegian women. Pharmacoepidem. S. 13 (6), 371-380. doi: $10.1002 /$ pds. 945

Nyeko, R., Tumwesigye, N. M., and Halage, A. A. (2016). Prevalence and factors associated with use of herbal medicines during pregnancy among women 
attending postnatal clinics in Gulu district, Northern Uganda. BMC Pregnancy Childb. 16 (1), 296. doi: 10.1186/s12884-016-1095-5

Odou, P., Ferrari, N., Barthelemy, C., Brique, S., Lhermitte, M., Vincent, A., et al. (2005). Grapefruit juice-nifedipine interaction: possible involvement of several mechanisms. J. Clin. Pharm. Ther. 30 (2), 153-158. doi: 10.1111/j.13652710.2004.00618.x

Oken, B. S., Storzbach, D. M., and Kaye, J. A. (1998). The efficacy of Ginkgo biloba on cognitive function in Alzheimer disease. Arch. Neurol. 55 (11), 1409-1415. doi: 10.1001/archneur.55.11.1409

Onyiapat, J. L., Okafor, C., Okoronkwo, I., Anarado, A., Chukwukelu, E., Nwaneri, A., et al. (2017). Complementary and alternative medicine use: results from a descriptive study of pregnant women in Udi local Government area of Enugu state, Nigeria. BMC Complem. Altern. M. 17 (1), 189. doi: 10.1186/s12906-0171689-0

Ozgoli, G., Goli, M., and Simbar, M. (2009). Effects of ginger capsules on pregnancy, nausea, and vomiting. J. Altern. Complement. Med. 15 (3), 243246. doi: $10.1089 / \mathrm{acm} .2008 .0406$

Pallivalapila, A. R., Stewart, D., Shetty, A., Pande, B., Singh, R., and McLay, J. S. (2015). Use of complementary and alternative medicines during the third trimester. Obstet. Gynecol. 125 (1), 204-211. doi: 10.1097/AOG.0000000000000596

Panganai, T., and Shumba, P. (2016). The African Pitocin - a midwife's dilemma: the perception of women on the use of herbs in pregnancy and labour in Zimbabwe, Gweru. Pan. Afr. Med. J. 25, 9. doi: 10.11604/pamj.2016.25.9.7876

Pfizer (2018)."SOLU-MEDROL ${ }^{\circledR}$ (methylprednisolone sodium succinate for injection, USP): Label." Retrieved 16 May 2018, from https://www. accessdata.fda.gov/drugsatfda_docs/label/2018/011856s131lbl.pdf.

Pilija, V., Ivetic, V., Mihalj, M., Draganic-Gajic, S., and Popovic, M. (2004). Effects of ginkgo biloba extract on an experimental model of epilepsy. Med. Pregl. 57 (11-12), 541-544. doi: 10.2298/MPNS0412541P

Pongrojpaw, D., Somprasit, C., and Chanthasenanont, A. (2007). A randomized comparison of ginger and dimenhydrinate in the treatment of nausea and vomiting in pregnancy. J. Med. Assoc. Thai. 90 (9), 1703-1709.

QVAR® (beclomethasone dipropionate HFA), inhalation aerosol, for oral inhalation use. (2017). https://www.accessdata.fda.gov/drugsatfda_docs/label/ 2017/020911s029s030lbl.pdf. PublishedAccessed 16 May 2018.

Rahman, A. A., Sulaiman, S. A., Ahmad, Z., Daud, W. N., and Hamid, A. M. (2008). Prevalence and pattern of use of herbal medicines during pregnancy in tumpat district, kelantan. Malays J. Med. Sci. 15 (3), 40-48.

Rajapakse, N. W., Head, G. A., and Kaye, D. M. (2016). Say NO to Obesity-Related Hypertension: role of the L-Arginine-Nitric Oxide pathway. Hypertension 67 (5), 813-819. doi: 10.1161/HYPERTENSIONAHA.116.06778

Rayburn, W. F., Christensen, H. D., and Gonzalez, C. L. (2000). Effect of antenatal exposure to Saint John's wort (Hypericum) on neurobehavior of developing mice. Am. J. Obstet. Gynecol. 183 (5), 1225-1231. doi: 10.1067/mob.2000.108889

Rayburn, W. F., Gonzalez, C. L., Christensen, H. D., Harkins, T. L., and Kupiec, T. C. (2001). Impact of hypericum (St.-John's-wort) given prenatally on cognition of mice offspring. Neurotoxicol. Teratol. 23 (6), 629-637. doi: 10.1016/S0892-0362(01)00179-9

Roeder, E., Wiedenfeld, H., and Edgar, J. A. (2015). Pyrrolizidine alkaloids in medicinal plants from North America. Pharmazie 70 (6), 357-367.

Romaszko, E., Wiczkowski, W., Romaszko, J., Honke, J., and Piskula, M. K. (2014). Exposure of breastfed infants to quercetin after consumption of a single meal rich in quercetin by their mothers. Mol. Nutr. Food Res. 58 (2), 221-228. doi: $10.1002 / \mathrm{mnfr} .201200773$

Samadi, S., Khadivzadeh, T., Emami, A., Moosavi, N. S., Tafaghodi, M., and Behnam, H. R. (2010). The effect of Hypericum perforatum on the wound healing and scar of cesarean. J. Altern. Complement. Med. 16 (1), 113-117. doi: 10.1089/acm.2009.0317

Sammons, H. M., Gubarev, M. I., Krepkova, L. V., et al. (2016). Herbal medicines: challenges in the modern world. Part 2. European Union and Russia. Expert Rev. Clin. Pharmacol. 9 (8), 1117-1127. doi: 10.1080/17512433.2016.1189326

Schulz, V. (2001). Incidence and clinical relevance of the interactions and side effects of Hypericum preparations. Phytomedicine 8 (2), 152-160.

Sharifzadeh, F., Kashanian, M., Koohpayehzadeh, J., Rezaian, F., Sheikhansari, N., and Eshraghi, N. (2018). A comparison between the effects of ginger, pyridoxine (vitamin B6) and placebo for the treatment of the first trimester nausea and vomiting of pregnancy (NVP). J. Matern. Fetal Neonatal. Med. 31 (19), 2509-2514. doi: 10.1080/14767058.2017.1344965
Simpson, M., Parsons, M., Greenwood, J., and Wade, K. (2001). Raspberry leaf in pregnancy: its safety and efficacy in labor. J. Midwifery Womens Health 46 (2), 51-59. doi: 10.1016/S1526-9523(01)00095-2

SINGULAIR® (montelukast sodium) Tablets, Chewable Tablets, and Oral Granules. (2016). https://www.accessdata.fda.gov/drugsatfda_docs/label/ 2016/020829s069,020830s071,021409s047lbl.pdf. Published Accessed 16 May 2018.

Smeriglio, A., Tomaino, A., and Trombetta, D. (2014). Herbal products in pregnancy: experimental studies and clinical reports. Phytother. Res. 28 (8), 1107-1116. doi: 10.1002/ptr.5106

Smith, C., Crowther, C., Willson, K., Hotham, N., and McMillian, V. (2004). A randomized controlled trial of ginger to treat nausea and vomiting in pregnancy. Obstet. Gynecol. 103 (4), 639-645. doi: 10.1097/01.AOG.0000118307.19798.ec

SOLU-MEDROL $®$ (methylprednisolone sodium succinate for injection, USP). (2018). https://www.accessdata.fda.gov/drugsatfda_docs/label/2018/ 011856s131lbl.pdf. Published 2018. Accessed 16 May.

Spinella, M. (2001). Herbal Medicines and Epilepsy: the potential for benefit and adverse effects. Epilepsy Behav. 2 (6), 524-532. doi: 10.1006/ebeh.2001.0281

Sprouse, A. A., and van Breemen, R. B. (2016). Pharmacokinetic interactions between drugs and botanical dietary supplements. Drug Metab. Dispos. 44 (2), 162-171. doi: 10.1124/dmd.115.066902

Sripramote, M., and Lekhyananda, N. (2003). A randomized comparison of ginger and vitamin B6 in the treatment of nausea and vomiting of pregnancy. J. Med. Assoc. Thai. 86 (9), 846-853.

Tabassum, N., and Ahmad, F. (2011). Role of natural herbs in the treatment of hypertension. Pharmacogn. Rev. 5 (9), 30-40. doi: 10.4103/0973-7847.79097

Tabatabaee, M. (2011). Use of herbal medicine among pregnant women referring to Valiasr hospital in Kazeroon, Fars, South of Iran. J. Med. Plants Res. 1 (37), 96-108.

Takei, A. , Nagashima, G., Suzuki, R., Hokaku, H., Takahashi, M., Miyo, T., et al. (1997). Fujimoto t. Meningoencephalocele associated with Tripterygium wilfordii treatment. Pediatr. Neurosurg. 27 (1), 45-48. doi: 10.1159/000121224

Tam, T. W., Liu, R., Saleem, A., Arnason, J. T., Krantis, A., and Foster, B. C. (2014). Cytochrome P450 3A4 and 2D6-mediated metabolism of leisure and medicinal teas. J. Pharm. Pharm. Sci. 17 (3), 294-301. doi: 10.18433/J3902H

Tamborini, A., and Taurelle, R. (1993). [Value of standardized Ginkgo biloba extract (EGb 761) in the management of congestive symptoms of premenstrual syndrome]. Rev. Fr. Gynecol. Obstet. 88 (7-9), 447-457.

Tamuno, I., Omole-Ohonsi, A., and Fadare, J. (2010). Use of herbal Medicine among pregnant women attending a tertiary hospital in Northern Nigeria. Internet J. Gynecol. Obstetrics. 15 (2). doi: 10.5580/2932

Tanaka, T., and Takahashi, R. (2013). Flavonoids and asthma. Nutrients 5 (6), 2128-2143. doi: 10.3390/nu5062128

Tang, L., Lee, A. H., Binns, C. W., Hui, Y. V., and Yau, K. K. W. (2016). Consumption of Chinese herbal medicines during pregnancy and postpartum: a prospective cohort study in China. Midwifery 34, 205-210. doi: 10.1016/j.midw.2015.11.010

Taylor, L. H., and Kobak, K. A. (2000). An open-label trial of St. John's Wort (Hypericum perforatum) in obsessive-compulsive disorder. J. Clin. Psychiatry 61 (8), 575-578. doi: 10.4088/JCP.v61n0806

Teng, L., Zu, Q., Li, G., et al. (2016). Herbal medicines: challenges in the modern world. Part 3. China and Japan. Expert Rev. Clin. Pharmacol. 9 (9), 1225-1233. doi: $10.1080 / 17512433.2016 .1195263$

Teva Respiratory, LLC (2017). "QVAR® (beclomethasone dipropionate HFA), inhalation aerosol, for oral inhalation use: Highlights of prescribing information." Retrieved 16 May 2018, from https://www.accessdata.fda.gov/ drugsatfda_docs/label/2017/020911s029s030lbl.pdf

Teni, F. S., Birru, E. M., Surur, A. S., et al. (2017). Pattern and predictors of medicine use among households in Gondar Town, northwestern Ethiopia: a community-based medicine utilization study. BMC Res. Notes 10 (1), 357. doi: 10.1186/s13104-017-2669-7

Tiran, D. (2003). The use of herbs by pregnant and childbearing women: a riskbenefit assessment. Complement. Ther. Nurs. Midwifery 9 (4), 176-181. doi: 10.1016/S1353-6117(03)00045-3

Townsend, R., O'Brien, P., and Khalil, A. (2016). Current best practice in the management of hypertensive disorders in pregnancy. Integr. Blood Press Control 9, 79-94. doi: 10.2147/IBPC.S77344

Unger, M., and Frank, A. (2004). Simultaneous determination of the inhibitory potency of herbal extracts on the activity of six major cytochrome P450 enzymes using liquid chromatography/mass spectrometry and automated 
online extraction. Rapid Commun. Mass Spectrom. 18 (19), 2273-2281. doi: $10.1002 / \mathrm{rcm} .1621$

United States Congress. Dietary Supplement Health and Education Act of 1994" (DSHEA), Public law 103-417, available at: https://ods.od.nih.gov/About/ dshea_wording.aspx. In.

Varga, C. A., and Veale, D. J. (1997). Isihlambezo: utilization patterns and potential health effects of pregnancy-related traditional herbal medicine. Soc. Sci. Med. 44 (7), 911-924. doi: 10.1016/S0277-9536(96)00104-9

Veale, D. J., Katsoulis, L. C., Kaido, T., Arangies, N. S., Olive, D. W., Dekker, T., et al. (1998). The pharmacological assessment of herbal oxytocics used in South African traditional medicine. BioMed. Environ. 2, 216-222.

Veale, D. J., Furman, K. I., and Oliver, D. W. (1992). South African traditional herbal medicines used during pregnancy and childbirth. J. Ethnopharmacol. 36 (3), 185-191. doi: 10.1016/0378-8741(92)90043-Q

Viale, L., Allotey, J., Cheong-See, F., et al. (2015). Epilepsy in pregnancy and reproductive outcomes: a systematic review and meta-analysis. Lancet 386 (10006), 1845-1852. doi: 10.1016/S0140-6736(15)00045-8

Vutyavanich, T., Kraisarin, T., and Ruangsri, R. (2001). Ginger for nausea and vomiting in pregnancy: randomized, double-masked, placebo-controlled trial. Obstet. Gynecol. 97 (4), 577-582. doi: 10.1097/00006250-20010400000017

Wang, Z., Gorski, J. C., Hamman, M. A., Huang, S. M., Lesko, L. J., and Hall, S. D. (2001). The effects of St John's wort (Hypericum perforatum) on human cytochrome P450 activity. Clin. Pharmacol. Ther. 70 (4), 317-326. doi: 10.1016/S0009-9236(01)17221-8

Willetts, K. E., Ekangaki, A., and Eden, J. A. (2003). Effect of a ginger extract on pregnancy-induced nausea: a randomised controlled trial. Aust. N. Z. J. Obstet. Gynaecol. 43 (2), 139-144. doi: 10.1046/j.0004-8666.2003.00039.x

Wing, D. A., Rumney, P. J., Preslicka, C. W., and Chung, J. H. (2008). Daily cranberry juice for the prevention of asymptomatic bacteriuria in pregnancy: a randomized, controlled pilot study. J. Urol. 180 (4), 1367-1372. doi: 10.1016/ j.juro.2008.06.016

World Health Organization, Traditional, complementary and integrative medicine. Definitions. (2013). Abailable at: http://www.who.int/traditionalcomplementary-integrative-medicine/en/. Published Accessed July 9, 2018.

Worth, H., and Dethlefsen, U. (2012). Patients with asthma benefit from concomitant therapy with cineole: a placebo-controlled, double-blind trial. J. Asthma. 49 (8), 849-853. doi: 10.3109/02770903.2012.717657

Yamaori, S., Ebisawa, J., Okushima, Y., Yamamoto, I., and Watanabe, K. (2011a). Potent inhibition of human cytochrome P450 3A isoforms by cannabidiol: role of phenolic hydroxyl groups in the resorcinol moiety. Life Sci. 88 (15-16), 730736. doi: 10.1016/j.lfs.2011.02.017

Yamaori, S., Okamoto, Y., Yamamoto, I., and Watanabe, K. (2011b). Cannabidiol, a major phytocannabinoid, as a potent atypical inhibitor for CYP2D6. Drug Metab. Dispos. 39 (11), 2049-2056. doi: 10.1124/dmd.111.041384

Yamaori, S., Kinugasa, Y., Jiang, R., Takeda, S., Yamamoto, I., and Watanabe, K. (2015). Cannabidiol induces expression of human cytochrome P450 1A1 that is possibly mediated through aryl hydrocarbon receptor signaling in HepG2 cells. Life Sci. 136, 87-93. doi: 10.1016/j.lfs.2015.07.007

Yang, N., Liang, B., Srivastava, K., et al. (2013). The Sophora flavescens flavonoid compound trifolirhizin inhibits acetylcholine induced airway smooth muscle contraction. Phytochemistry 95, 259-267. doi: 10.1016/j.phytochem.2013. 07.023
Yang, N., Patil, S., Zhuge, J., et al. (2013). Glycyrrhiza uralensis flavonoids present in anti-asthma formula, ASHMI, inhibit memory Th2 responses in vitro and in vivo. Phytother. Res. 27 (9), 1381-1391. doi: 10.1002/ptr.4862

Yang, N., Zhang, H., Cai, X., and Shang, Y. (2018). Epigallocatechin-3-gallate inhibits inflammation and epithelialmesenchymal transition through the PI3K/ AKT pathway via upregulation of PTEN in asthma. Int. J. Mol. Med. 41 (2), 818-828. doi: 10.3892/ijmm.2017.3292

Yoshioka, M., Ohnishi, N., Sone, N., et al. (2004). Studies on interactions between functional foods or dietary supplements and medicines. III. Effects of ginkgo biloba leaf extract on the pharmacokinetics of nifedipine in rats. Biol. Pharm. Bull. 27 (12), 2042-2045. doi: 10.1248/bpb.27.2042

Yoshioka, M., Ohnishi, N., Koishi, T., et al. (2004). Studies on interactions between functional foods or dietary supplements and medicines. IV. Effects of ginkgo biloba leaf extract on the pharmacokinetics and pharmacodynamics of nifedipine in healthy volunteers. Biol. Pharm. Bull. 27 (12), 2006-2009. doi: 10.1248/bpb.27.2006

Zafar, S., Najam, Y., Arif, Z., and Hafeez, A. (2016). A randomized controlled trial comparing Pentazocine and Chamomilla recutita for labor pain relief. Homeopathy 105 (1), 66-70. doi: 10.1016/j.homp.2015.09.003

Zaffani, S., Cuzzolin, L., and Benoni, G. (2006). Herbal products: behaviors and beliefs among Italian women. Pharmacoepidemiol. Drug Saf. 15 (5), 354-359. doi: $10.1002 /$ pds. 1190

Zamawe, C., King, C., Jennings, H. M., and Fottrell, E. (2018). Associations between the use of herbal medicines and adverse pregnancy outcomes in rural Malawi: a secondary analysis of randomised controlled trial data. BMC Complement. Altern. Med. 18 (1), 166. doi: 10.1186/s12906-018-2203-z

Ziaei, S., Hantoshzadeh, S., Rezasoltani, P., and Lamyian, M. (2001). The effect of garlic tablet on plasma lipids and platelet aggregation in nulliparous pregnants at high risk of preeclampsia. Eur. J. Obstet. Gynecol. Reprod. Biol. 99 (2), 201206. doi: 10.1016/S0301-2115(01)00384-0

Ziegler, G., Ploch, M., Miettinen-Baumann, A., and Collet, W. (2002). Efficacy and tolerability of valerian extract LI 156 compared with oxazepam in the treatment of non-organic insomnia-a randomized, double-blind, comparative clinical study. Eur. J. Med. Res. 7 (11), 480-486.

Zisaki, A., Miskovic, L., and Hatzimanikatis, V. (2015). Antihypertensive drugs metabolism: an update to pharmacokinetic profiles and computational approaches. Curr. Pharm. Des. 21 (6), 806-822. doi: 10.2174/ 1381612820666141024151119

Conflict of Interest: CS is Specialty Chief Editor in Frontiers Obstetric and Pediatric Pharmacology Journal. All other authors have no relevant affiliations or financial involvement with any organization or entity with a financial interest in or financial conflict with the subject matter or materials discussed in the manuscript. This includes employment, consultancies, honoraria, stock ownership or options, expert testimony, grants or patents received or pending, or royalties.

Copyright (c) 2020 Illamola, Amaeze, Krepkova, Birnbaum, Karanam, Job, Bortnikova, Sherwin and Enioutina. This is an open-access article distributed under the terms of the Creative Commons Attribution License (CC BY). The use, distribution or reproduction in other forums is permitted, provided the original author(s) and the copyright owner(s) are credited and that the original publication in this journal is cited, in accordance with accepted academic practice. No use, distribution or reproduction is permitted which does not comply with these terms. 